\title{
The Interplay between Uremic Toxins and Albumin, Membrane Transporters and Drug Interaction
}

\author{
Regiane Stafim da Cunha ${ }^{1}{ }^{1}$, Carolina Amaral Bueno Azevedo ${ }^{1}$, Carlos Alexandre Falconi ${ }^{2}$, \\ Fernanda Fogaça Ruiz ${ }^{2}$, Sophie Liabeuf ${ }^{3}$ (i), Marcela Sorelli Carneiro-Ramos ${ }^{2}$ (D) \\ and Andréa Emilia Marques Stinghen $1, *$ (B)
}

Citation: Cunha, R.S.d.; Azevedo,

C.A.B.; Falconi, C.A.; Ruiz, F.F.;

Liabeuf, S.; Carneiro-Ramos, M.S.;

Stinghen, A.E.M. The Interplay

between Uremic Toxins and Albumin,

Membrane Transporters and Drug

Interaction. Toxins 2022, 14, 177.

https://doi.org/10.3390/

toxins 14030177

Received: 31 January 2022

Accepted: 24 February 2022

Published: 26 February 2022

Publisher's Note: MDPI stays neutral with regard to jurisdictional claims in published maps and institutional affiliations.

Copyright: (C) 2022 by the authors. Licensee MDPI, Basel, Switzerland This article is an open access article distributed under the terms and conditions of the Creative Commons Attribution (CC BY) license (https:// creativecommons.org/licenses/by/ $4.0 /)$.
1 Experimental Nephrology Laboratory, Basic Pathology Department, Universidade Federal do Paraná, Curitiba 81531-980, Brazil; regidacunha@ufpr.br (R.S.d.C.); carolina.amaral1@ufpr.br (C.A.B.A.)

2 Laboratory of Cardiovascular Immunology, Center of Natural and Human Sciences (CCNH), Federal University of ABC, Santo André 09210-580, Brazil; falconi.familia@gmail.com (C.A.F.); fernandafogaca1@gmail.com (F.F.R.); marcela.ramos@ufabc.edu.br (M.S.C.-R.)

3 Department of Pharmacology, Amiens University Medical Center, 80054 Amiens, France; liabeuf.sophie@chu-amiens.fr

* Correspondence: andreastinghen@ufpr.br

\begin{abstract}
Uremic toxins are a heterogeneous group of molecules that accumulate in the body due to the progression of chronic kidney disease (CKD). These toxins are associated with kidney dysfunction and the development of comorbidities in patients with CKD, being only partially eliminated by dialysis therapies. Importantly, drugs used in clinical treatments may affect the levels of uremic toxins, their tissue disposition, and even their elimination through the interaction of both with proteins such as albumin and cell membrane transporters. In this context, protein-bound uremic toxins (PBUTs) are highlighted for their high affinity for albumin, the most abundant serum protein with multiple binding sites and an ability to interact with drugs. Membrane transporters mediate the cellular influx and efflux of various uremic toxins, which may also compete with drugs as substrates, and both may alter transporter activity or expression. Therefore, this review explores the interaction mechanisms between uremic toxins and albumin, as well as membrane transporters, considering their potential relationship with drugs used in clinical practice.
\end{abstract}

Keywords: uremic toxins; albumin; cell transporters

Key Contribution: This review addresses key factors and new insights into the relationship of uremic toxins with albumin and cell membrane transporters, as well as potential drug interactions, which may have implications for tissue disposition and elimination of both uremic toxins and drugs in patients with CKD.

\section{Introduction}

Kidney diseases were the 10th leading cause of death worldwide in 2019, according to the World Health Organization (WHO). Their mortality rate has increased approximately $37.4 \%$ in 19 years. One of the main consequences of the loss of renal function is an accumulation of uremic toxins in the body, affecting the various tissues and organs, including the cardiovascular system [1]. The biological effects promoted by uremic toxins depend on the relationship between production, degradation, and excretion, in addition to cytoplasmic distribution and the presence of inhibiting or promoting agents of the toxin's action [2].

The European Uremic Toxin Work Group (EUTox) reports that uremic toxins can be classified into three groups due to their physicochemical characteristics and their behavior during dialysis [1]: (I) Small-water soluble compounds (molecular weight $<500 \mathrm{Da}$ ), such as creatinine and urea; (II) Medium compounds (peptides with molecular weight >500 Da), such as cystatin- $C$ and $\beta_{2}$-microglobulin, which can only be removed by large pore size 
dialysis membranes; and (III) Protein-bound uremic toxins (PBUTs), such as indoles and phenols, which come from dietary amino acid metabolism and are poorly filtered by the dialytic membrane.

Most of the small-water soluble compounds are well known, and some can be used in the diagnosis of kidney diseases, such as serum creatinine and blood urea nitrogen (BUN) which are classic biomarkers in the progress of chronic kidney disease (CKD). Trimethylamine- $N$-oxide (TMAO) is in this same group, a uremic toxin associated with an increased risk of developing cardiovascular diseases (CVD), including cardiac dysfunction and atherosclerosis [3,4]. Another small-water soluble compound is inorganic phosphorus (Pi), which may not be considered as uremic toxin for some authors, but has a clear role in CVD progression. Hyperphosphatemia has been associated with accelerating the progress of renal dysfunction and is also correlated with a higher mortality rate from CVD and peripheral and visceral vascular calcification [2].

It is important to mention fibroblast growth factor 23 (FGF-23), $\beta_{2}$-microglobulin, parathyroid hormone (PTH), and pro-inflammatory molecules such as interleukin-6 (IL-6) among the medium compounds [5,6]. High levels of these toxins contribute to progressive renal structural damage; however, they are fundamental to mineral homeostasis maintenance in a healthy organism.

PBUTs stand out for their high affinity for proteins, particularly serum albumin, making their removal by dialysis therapies difficult. Tubular secretion plays a key role in the renal elimination of these uremic toxins, with the residual renal function being an important factor in uremic levels in patients with advanced CKD [7]. Regarding PBUTs, it is important to highlight that there are few studies that have addressed these molecules, and they demand attention from the scientific community due to their behavior during dialysis, for example [5,8,9]. Given the relevant role of uremic toxins in CKD, in the next topic, we address the main PBUTs, followed by how the interaction with albumin occurs.

\section{Protein-Bound Uremic Toxins (PBUTs)}

\subsection{Indoxyl Sulfate (IS)}

Indoxyl sulfate (IS) constitutes one PBUT and is a product of the bacterial metabolism of dietary tryptophan by bacteria in the gut and converted to indole, which crosses the intestinal barrier and reaches the liver where it is converted to indoxyl, and later sulfated to IS ions, in the way it is found in the bloodstream and tissue of patients with compromised renal function [10-12]. About $90 \%$ of it in blood plasma is primarily bound to serum proteins such as albumin, and this binding causes its excretion to primarily occur by proximal tubular secretion and then by glomerular filtration [13].

Patients with CKD have a total IS concentration surpassing $500 \mu \mathrm{M}$ compared to 0.1-2.39 $\mu \mathrm{M}$ in patients with healthy kidney functions [14]. As previously mentioned, the dialytic membrane pores do not effectively remove IS since $90 \%$ of it is bound to serum albumin, making the complex too large to be filtered. This retention is associated with diverse harmful effects in other organs, such as alterations to thyroid function, endothelial dysfunction, smooth muscle cell proliferation, and atherosclerosis [15,16]. IS is related to many harmful effects to the organism, with a hypertrophic effect in cardiomyocytes through the activation of the mitogen-activated protein kinase (MAPK) and nuclear factor$\mathrm{KB}(\mathrm{NF}-\mathrm{KB})$ pathways among them, in turn indicating that this toxin has a crucial role in developing cardiac hypertrophy under uremic conditions $[17,18]$. Another effect of IS is the activation of proinflammatory macrophages which generate an immune dysfunction. This activation is mediated by the uptake through transporters, including OATP2B1, which is an important mediator of inflammatory process signaling [19].

\section{2. $p$-Cresyl Sulfate (PCS)}

$p$-Cresyl Sulfate (PCS) is another PBUT generated from the metabolism of tyrosine and phenylalanine, two aromatic amino acids which are metabolized by bacteria from intestines. This molecule has a low molecular weight (108 Da), as with IS [2,5]. p-Cresol 
suffers sulfation and glucuronidation in the mucosa in the distal part of the colon of the large intestine and liver in the degradation process, generating PCS and $p$-cresylglucoronate [20]. As $p$-cresol is promptly metabolized, uremic patients show normal levels of these compounds similar to healthy people. Thus, PCS is the conjugated form of $p$-cresol with evident retention in the bloodstream of patients with CKD [21]. Serum concentration rates range from $2.8 \pm 1.7 \mathrm{mg} / \mathrm{L}(14.9 \pm 9.0 \mu \mathrm{M}) 7$ and $6.6 \pm 3.7 \mathrm{mg} / \mathrm{L}$ $(35.1 \pm 19.7 \mu \mathrm{M})$ in patients without serious renal impairment. These concentrations in patients with end-stage CKD can range from $21.8 \pm 12.4 \mathrm{mg} / \mathrm{L}(115.8 \pm 65.9 \mu \mathrm{M})$ to $106.9 \pm 44.6 \mathrm{mg} / \mathrm{L}(568.0 \pm 237.0 \mu \mathrm{M})$, both quantified by UPLC in serum and LC-MS-MS in plasma, respectively $[20,21]$.

Several studies point out the damage caused by PCS accumulation, such as smooth muscle cell lesions, endothelial dysfunction, coagulation disturbances, leukocyte activation, cardiac fibrosis, and metabolic disorders, including insulin resistance [21,22]. Other works have shown a deleterious effect of PCS in specific renal and cardiac cells, contributing to decrease glutathione levels promoting redox unbalance [23]. Consequently, it is possible to observe cardiac dysfunction, facilitating cardiomyocyte apoptosis and mitochondrial hyperfusion [8,24]. All effects demonstrate that this compound is linked to cardiovascular damage and contributes to the increase in mortality and cardiovascular events in CKD $[2,25]$.

\subsection{Indole-3-Acetic Acid (IAA)}

In addition to IS, indole-3-acetic acid (IAA) is a PBUT derived from the gut metabolism of dietary tryptophan with a molecular weight of $264.27 \mathrm{Da}$ [26,27]. Tryptophan-derived uremic toxins are agonists of the aryl hydrocarbon receptor (AhR) complex, and their accumulation in patients with CKD may activate the AhR [28], which leads to pro-oxidant, proinflammatory, pro-coagulant, and pro-apoptotic effects. IAA can also induce cyclooxygenase2, worsening the inflammatory state and increasing oxidative stress [29].

Beyond the classic and canonical actions of AhR activation, the non-canonical AhR signaling after IS or IAA stimulation is responsible for blocking the cell cycle and suppressing the S-phase genes. Some studies have shown the potential carcinogenesis control combined with an increase in inflammatory cytokine expression through NF-kB. Moreover, the activation of AhR can also promote proteolysis of the endoplasmic reticulum (ER), assembling the ubiquitin ligase complex [30].

IAA has been found to stimulate glomerular sclerosis and interstitial fibrosis, accelerating renal damage and the progression of CKD [31]. In a study with transplanted and non-transplanted patients with CKD, Liabeuf et al. (2020) demonstrated that free and total IAA gradually increased with CKD progression and that IAA levels were elevated at the transplant time but substantially decreased one month after transplantation [26]. Moreover, the free IAA level predicted overall mortality and cardiovascular events in the non-transplanted CKD cohort [26].

\subsection{3-Carboxy-4-methyl-5-propyl-2-furanpropionate (CMPF)}

3-Carboxy-4-methyl-5-propyl-2-furanpropionate (CMPF) is one of the major metabolites of furan fatty acids and shows incredible protein-binding affinity reaching almost $100 \%$ binding with site I of albumin; thus, it is not removed by conventional dialysis therapies $[32,33]$. CMPF plasma levels can remain high even 90 days after a successful kidney transplant [34]. The source of elevated levels of circulating CMPF is still unknown, and the consequences of its accumulation are still unclear $[35,36]$. However, it was demonstrated that CMPF is elevated in diabetes and acts directly in $\beta$ cells, dysregulating key transcription factors, eventually leading to reduced insulin biosynthesis, and inducing oxidative stress [37]. CMPF in CKD directly interacts with oxygen radicans and can enhance the production of reactive oxygen species (ROS) in HK-2 cells and consequently induce cell damage [38]. Given its role in oxidative stress, CMPF is often associated with uremic toxins with cardiovascular relevance [39,40]. However, a study conducted by Luce et al. (2018) 
with patients in hemodialysis showed that elevated serum CMPF levels were not associated with mortality or cardiovascular mortality in that cohort but were positively correlated with nutritional parameters and lean mass and is significantly elevated in patients without protein-energy wasting [41].

\section{Interaction between Uremic Toxins and Albumin}

Human serum albumin (HSA) is the most abundant protein in human plasma, representing $50-60 \%$ of the total plasma proteins, the main protein responsible for maintaining the colloid osmotic pressure of the blood. HSA is a $66 \mathrm{kDa}$ monomer that predominantly adopts a heart-shaped tertiary structure, containing three homologous helical domains (I-III) divided into A and B subdomains. HSA displays incredible binding capacity, serving as a carrier for many endogenous and exogenous molecules such as fatty acids, hemin, thyroxin, bilirubin, and a wide variety of drugs such as warfarin, diazepam, and ibuprofen, which usually bind to one of the two primary sites [42-44]. HSA binding improves the plasma solubility of these drugs but also reduces their free active concentration [45]. HSA can bind to peptides and proteins under physiological conditions, which impacts proteomic and biomarker studies, as the presence of binding and unbinding forms of these proteins can affect their detection and clearance [46]. Lastly, HSA is known to wield antioxidant properties in plasma, being the major source of reduced sulfhydryl groups, which act as scavengers of reactive oxygen species (ROS) and reactive nitrogen species (RNS) and can limit the production of these reactive species by binding free $\mathrm{Cu}^{2+}$, an ion that is known to be important in quickening the production of free radicals [47]. In addition, increased oxidative stress can induce oxidative modifications of HSA, including glycation, disulfide bond formation, and carbonylation, which can alter its binding properties, thus increasing or decreasing ligand affinity [42,48-50].

Oxidative stress has a key role in CKD development and is already present in its early stages [51]. Enhanced oxidative stress substantially contributes to CVD complications and further impairment of renal function with CKD progression. The HSA molecule appears to be altered in patients undergoing hemodialysis, which results in impairment of its physiological activities [52] and presents low antioxidant activity, capable of inducing an oxidative burst of neutrophils [53,54]. Moreover, the oxidized HSA levels are significantly increased with the decrease of renal function [55].

Various CKD-associated metabolic disturbances may alter drug distribution and trigger a CKD stage- decrease in albumin drug binding. The small water-soluble molecule urea can lead to post-translational carbamylation of proteins and thus changes in the latter's structure and function [56,57]. Indeed, plasma from CKD patients presents varying degrees of plasma protein carbamylation correlating with the values of free plasma salicylate [58].

One of the main roles of HSA in the context of CKD is its capacity to bind with uremic toxins, especially PCS and IS. Recent studies report that IS is present in both I and II binding sites, with a preference for site II [43]. In contrast, PCS is present within site II $[59,60]$ and possibly an unknown binding site, according to results achieved by Li et al. (2022) [43]. Figure 1 shows PBUTs and drugs that bind to sites I and II of albumin. Once in the bloodstream, about 85-95\% of both IS and PCS bind to HSA. Albumin-toxin binding can be altered by the concentration of available albumin in plasma or by albumin updating due to factors such as heat [61].

Hirata et al. recently investigated the relationship between the binding of aripiprazole, an antipsychotic agent, and the concentration of uremic toxins. The binding of aripiprazole in the cases of renal failure was reduced significantly, compared with the same values for healthy adults. An association was found between the ARP binding rate and the concentration of toxins, including IS and PCS [62].

In a cohort of 403 kidney transplant recipients, André et al. reported that the blood tacrolimus concentration was significantly associated with plasma IS, PCS, and urea levels. The authors' hypothesis was that IS and PCS bind to albumin with a high affinity and might directly compete for tacrolimus binding sites on the protein, whereas urea might 
carbamylate albumin and thus modify tacrolimus binding. The blood concentration of cyclosporine (which mainly binds to lipoprotein rather than albumin) was not associated with plasma IS, PCS, and urea levels [63].

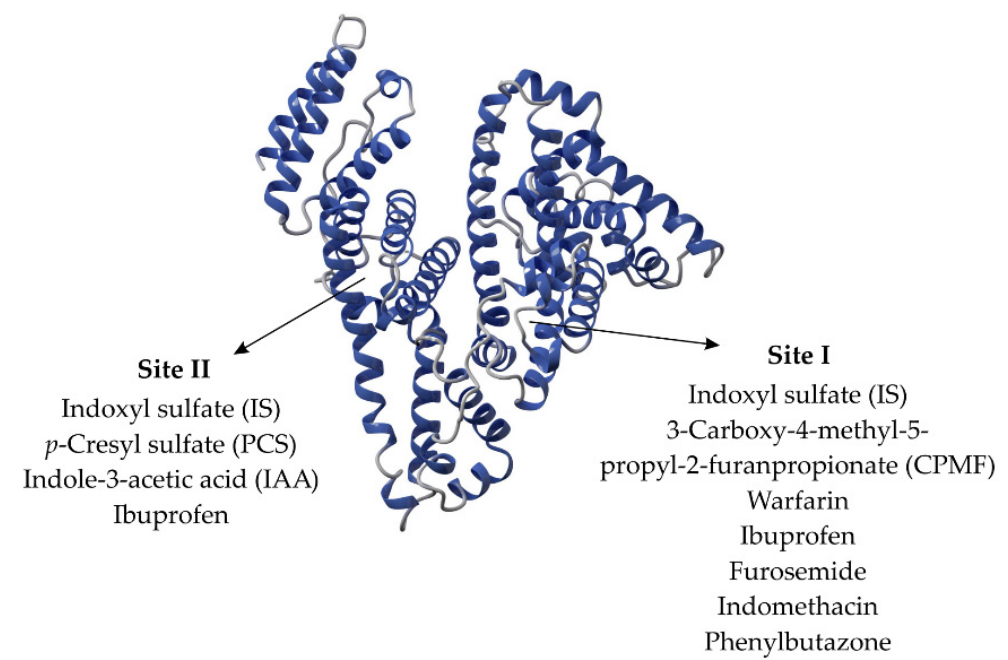

Figure 1. Albumin binding sites with PBUTs and drugs.

The binding of these toxins to HSA is problematic because they form a complex which is too large to be removed by conventional dialysis treatment, leading to an accumulation of these toxins and (as mentioned above) diverse harmful effects to patients with CKD. Therefore, many treatment options have been described and studied in the last few years.

Meyers et al. (2004) described a mathematical model of the behavior of PBUTs during hemodialysis, relating their clearance directly with the free fraction. Thus, increasing the free fraction of PBUTs by disrupting their binding with albumin is one possible way to improve the removal of PBUTs [64]. Böhringer et al. (2015) modified hemodiafiltration (HDF) with the perfusion of hypertonic $\mathrm{NaCl}$ solution to increase the ionic strength (HDFIPIS), and their results showed that some PBUTs were removed more efficiently, however only the free fraction of IS was significantly increased by this method [65]. Yamamoto et al. (2019) examined the efficacy of activated carbon in adsorbing circulating PBUTs through direct hemoperfusion (DHP) In vitro, with their results showing that activated carbon can drastically adsorb IS, PCS, and IAA from the blood of hemodialysis patients [66]. However, the study did not assess the safety and biocompatibility of activated carbon for clinical use, and therefore more studies are needed to check its safety and efficacy.

Shi et al. (2019) studied the effects of ionic strength, $\mathrm{pH}$, and chemical displacers on the percentage protein binding (PB) of PBUTs, showing that the PB\% decreased with increasing ionic strength, but only a few changes occurred with the increased $\mathrm{pH}$ (6.0 to 8.5) [67]. Regarding chemical displacers, they studied ibuprofen, warfarin, phenylbutazone, indomethacin, furosemide, oleic acid, linoleic acid, and docosahexaenoic acid (DHA), which are known to be typical displacers of HSA sites I or II. The results showed that PCS, IS, and IAA were easily dissociated from albumin by these chemicals. The PB\% for CMPF, PCS, IS, and IAA was significantly decreased in the presence of free fatty acids, oleic acid, and linoleic acid. In addition, Tao et al. (2016) showed in vitro that a concentration of $1 \mathrm{mM}$ of ibuprofen could increase the free fraction of IS and PCS by a threefold ratio in uremic plasma [68]. Madero et al. (2019) demonstrated that $800 \mathrm{mg}$ of ibuprofen infused in the arterial bloodline between minutes 21 and 40 of conventional $4 \mathrm{~h}$ high-flux hemodialysis results in a 3-fold increase of the dialytic removal of IS and PCS, leading to a reduction of their serum levels, and which disappear after stopping the ibuprofen infusion [69]. There was no difference in the clearance levels of non-protein-bound toxins, such as urea and creatinine. Therefore, displacement of PBUTs is a very attractive method. However, not all PBUTs will be affected by the same displacer, leading to the concerns gathered by Van 
Biesen and Elliot (2019), such as the need for efficient and rapid clearance of the substances to be used as displacers. They also need to be inert because a combination of displacers is most likely to be necessary to displace a higher number of PBUTs [70].

Another method has recently revealed potential in removing PBTUs, namely liposomes. Shi et al. (2019) reported that the addition of liposomes to the dialysate significantly enhanced PBUTs removal without influencing the removal of small, water-soluble solutes [71]. In 2020, Shen et al. (2020) constructed linoleic acid-modified liposomes (LA-liposomes) as an indirect adsorbent in the dialysate [72]. The LA-liposomes showed good binding properties to the PBUTs, bilirubin, and bile acids. Additionally, the albumin binding of PBUTs was significantly inhibited by the addition of linoleic acid, enhancing the removal of PBUTs and showing the potential of combining indirect adsorbent (i.e., LA-liposomes) and a competitive displacer (i.e., LA) for removing protein-bound uremic toxins [72].

\section{Cell Membrane Transporters of Uremic Toxins}

Uremic toxins interact with membrane transporters, proteins which mediate the influx or efflux of these compounds into the cell. These toxins can activate signaling pathways upon entering the cell and modulate the cellular response under uremic conditions, contributing to the pathological process of CKD. The transport of uremic toxins across the cell membrane has been associated with representatives of the solute carrier (SLC) transporter and ATP-binding cassette (ABC) transporter superfamilies, which are known to transport a variety of endogenous and xenobiotic compounds and are also implicated in drug therapy. Importantly, membrane transporters are essential for the renal elimination of these compounds via tubular secretion. Therefore, it is suggested that the expression of these transporters may be related to the toxicity of uremic solutes that accumulate in the body with the CKD progression. A summary of cell membrane transporters that are involved in transporting or interacting with uremic toxins is presented in Figure 2 and Table 1.

Table 1. Cell membrane transporters that interact with uremic toxins and drugs.

\begin{tabular}{|c|c|c|c|c|}
\hline Protein & Gene & Tissue Distribution & Uremic Toxin Interaction & Drug Interaction \\
\hline OAT1 & SLC22A6 & Kidney & $\begin{array}{l}\text { PCS, IS, kynurenic acid, } \\
\text { hippuric acid }\end{array}$ & $\begin{array}{c}\text { Probenecid, } \beta \text {-lactam antibiotics, } \\
\text { nonsteroidal anti-inflammatory } \\
\text { drugs }\end{array}$ \\
\hline OAT2 & SLC22A7 & Kidney, liver & Creatinine & \\
\hline OAT3 & SLC22A8 & Kidney & $\begin{array}{l}\text { PCS, IS, kynurenic acid, } \\
\text { hippuric acid }\end{array}$ & $\begin{array}{c}\text { Probenecid, ciprofloxacin, } \\
\beta \text {-lactam antibiotics, nonsteroidal } \\
\text { anti-inflammatory drugs }\end{array}$ \\
\hline OCT2 & $S L C 22 A 2$ & Kidney & $\begin{array}{c}\text { Creatinine, TMAO, } \\
\text { methylguanidine, } \\
\text { guanidine, putrescine }\end{array}$ & $\begin{array}{l}\text { Metformin, cisplatin, cimetidine, } \\
\text { vandetanib, trimethoprim }\end{array}$ \\
\hline OCT3 & SLC22A3 & $\begin{array}{l}\text { Choroid plexus, skeletal muscle, } \\
\text { placenta, kidney }\end{array}$ & Creatinine & \\
\hline OATP4C1 & SLCO4C1 & Kidney & ADMA & $\begin{array}{c}\text { OATP4C1 expression is modulated } \\
\text { by statins }\end{array}$ \\
\hline PiT-1 & SLC20A1 & Endothelial cells, intestine, bones & $\mathrm{Pi}$ & \\
\hline PiT-2 & SLC20A2 & $\begin{array}{l}\text { Endothelial cells, intestine, bones, } \\
\text { kidney }\end{array}$ & $\mathrm{Pi}$ & \\
\hline $\mathrm{NaPi} 2 \mathrm{~B}$ & SLC34A2 & Intestine & $\mathrm{Pi}$ & $\begin{array}{l}\text { Nicotinic acid and nicotinamide } \\
\text { inhibit NaPi2B expression }\end{array}$ \\
\hline MATE1 & $S L C 47 A 1$ & Kidney, liver, heart & $\begin{array}{l}\text { TMAO, creatinine, } \\
\text { guanidine }\end{array}$ & $\begin{array}{c}\text { Trimethoprim, trospium, } \\
\text { ondansetron }\end{array}$ \\
\hline
\end{tabular}


Table 1. Cont.

\begin{tabular}{ccccc}
\hline Protein & Gene & Tissue Distribution & Uremic Toxin Interaction & Drug Interaction \\
\hline MATE2-K & SLC47A2 & Kidney & Creatinine, guanidine & Febuxostat \\
\hline BCRP & ABCG2 & $\begin{array}{c}\text { Kidney, intestine, blood vessels, } \\
\text { placenta }\end{array}$ & $\begin{array}{c}\text { PCS, IS, kynurenic acid, } \\
\text { TMAO, uric acid }\end{array}$ & TMAO \\
\hline MRP2 & $A B C C 2$ & $\begin{array}{c}\text { Kidney, liver, intestine, brain } \\
\text { capillary endothelium }\end{array}$ & $\begin{array}{c}\text { Methotrexate, nonsteroidal } \\
\text { anti-inflammatory drugs }\end{array}$ \\
\hline MRP4 & $A B C C 4$ & $\begin{array}{c}\text { Kidney, liver, intestine, brain } \\
\text { capillary endothelium }\end{array}$ & $\begin{array}{c}\text { Methotrexate, nonsteroidal } \\
\text { anti-inflammatory drugs }\end{array}$ \\
\hline & Abbreviations: ADMA, asymmetric dimethylarginine; IS, indoxyl sulfate; PCS, $p$-cresyl sulfate; Pi, inorganic
\end{tabular}
phosphate; TMAO, trimethylamine- $N$-oxide.

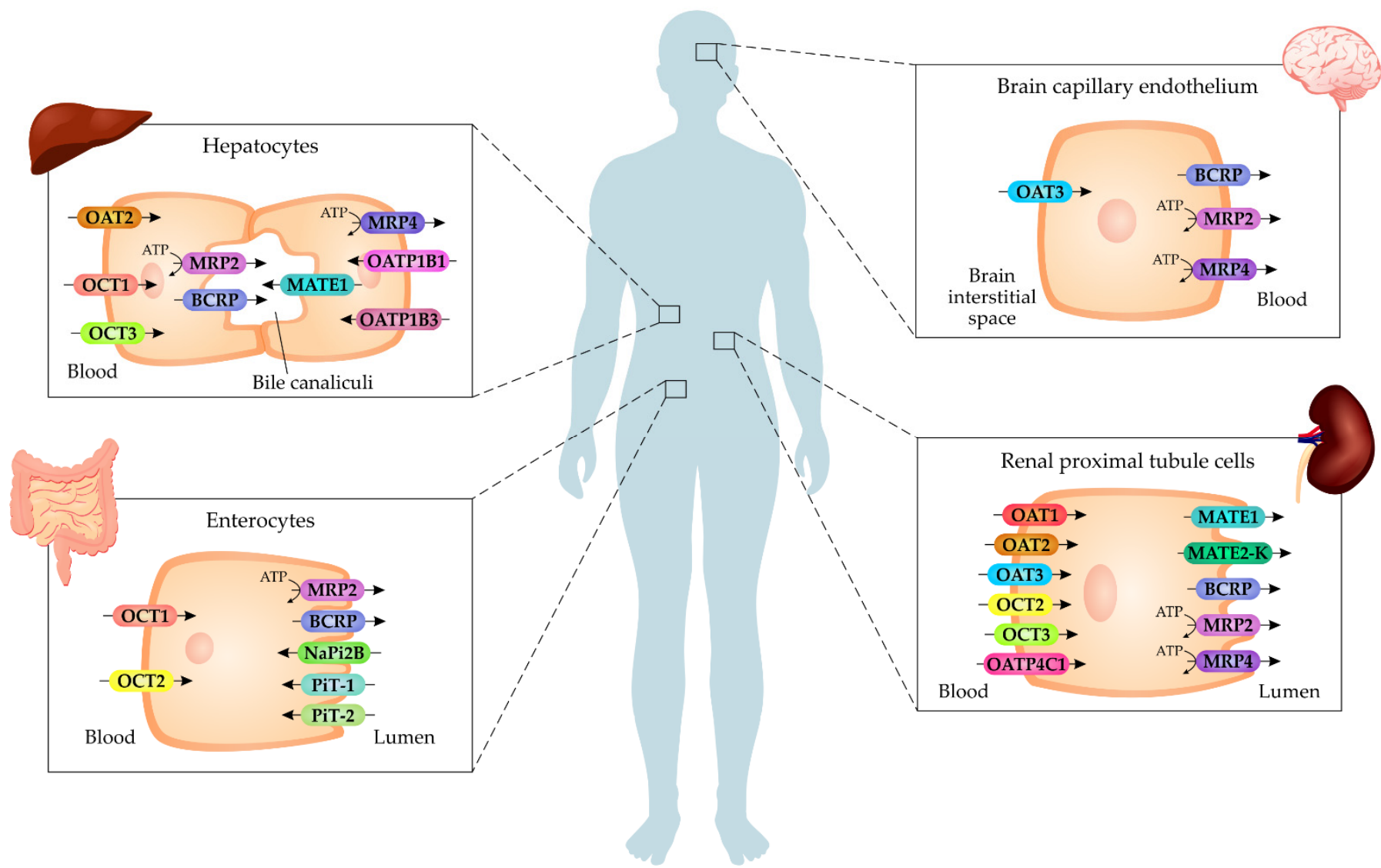

Figure 2. Cell membrane transporters that mediated transport of uremic toxins. Several transporters contribute to the cellular influx and efflux of uremic toxins across membranes, such as organic anion transporters (OATs), organic cation transporters (OCTs), organic anion-transporting polypeptides (OATPs), type-III sodium-dependent phosphate transporters (PiTs), multidrug and toxin extrusion (MATEs), the breast cancer resistance protein (BCRP), and multidrug resistance-associated proteins (MRPs). These transporters can be found in renal cells, hepatocytes, enterocytes, and endothelium.

\subsection{Organic Anions Transporters (OATs)}

Organic anion transporters (OATs) are polyspecific membrane transporters that perform the cellular influx of a wide variety of substrates, mainly organic anions, although some cations have also been identified as substrates $[73,74]$. Several uremic toxins, as well as many drugs, are organic anions that can compete for these transporters $[75,76]$. OATs belong to the SLC superfamily, specifically the SLC22A family. So far, the isoforms of OAT1-7, OAT10, and URAT1 have been identified in human tissues $[77,78]$. Regarding their structure, OATs have between 540 and 650 amino acids that are organized in 12 trans- 
membrane $\alpha$-helices domains with both $\mathrm{NH}_{2}$ and $\mathrm{COOH}$ terminations in the cytoplasm and multiple glycosylations in the extracellular loop [78].

OAT1 and OAT3, encoded by the SLC22A6 and SLC22A8 genes, respectively, are the most studied transporters of this family. Both proteins have an antiport-type transport mechanism in which substrates from the extracellular environment are captured in exchange for intracellular dicarboxylates $[79,80]$. They are found in the kidneys, mainly in the basolateral membrane of renal proximal tubule cells, where they participate in the tubular secretion of various compounds, including uremic toxins [77,80-82]. Furthermore, animal studies have shown that CKD may cause changes in the expression of OATs. These studies reported a decrease or no change in the expression of Oat1 and Oat3 in the kidneys of nephrectomized animals [83-86]. In contrast, nephrectomized rats treated orally with IS for ten weeks showed an increase in Oat1 levels in the renal tubules [87].

Metabolomic analyses have shown increased plasma levels of PCS, IS, and kynurenine uremic toxins in Oat1 knockout mice $[88,89]$. In addition to these same toxins, the Oat3 knockout mice also showed increased plasma CMPF and TMAO levels [89]. These data demonstrate that OAT1 and OAT3 are important for cellular uptake of several uremic toxins and are strongly related to their renal clearance. Some of these molecules have to be modified by phase 2 enzymes in the liver, demonstrating that OATs are key players in the gut-liver-kidney axis and suggesting an important role for OATs in proximal tubule metabolism [88,90,91]. Although OAT1 and OAT3 have overlapping substrates, literature data indicate that each one may have a greater or lesser contribution in the capture of specific substrates. PCS and IS seem to mainly be excreted by OAT3, while hippurate and IAA by OAT1 [92,93]. The basolateral uptake of PCS is inhibited by IS since its Km value is larger than the other, which may explain the high level of plasma concentration of this uremic toxin due to the competition in the urinary excretion in patients with CKD [93,94].

Several drugs also interact with OAT1 and OAT3, such as uricosuric agents, antivirals, $\beta$-lactam antibiotics, and non-steroidal anti-inflammatory drugs [95-98]. These drugs inhibit OATs in a competitive manner, such as probenecid and benzylpenicillin, or a noncompetitive manner, as in the case of telmisartan, which alters the conformation of the transporter and impairs its activity [99]. The inhibition of OATs consequently affects the cellular uptake of uremic toxins in the kidneys and other tissues which express the OATs. Studies have shown that probenecid, a well-known OATs inhibitor, significantly reduces the uptake of PCS by kidney cells [93,100]. Similarly, Favretto et al. (2017) demonstrated that probenecid decreases both PCS and IS uptake by endothelial cells [101]. In vitro studies also indicate that inhibiting the entry of uremic toxins attenuates their biological effects on various cell types. Blocking OATs with probenecid re-established the inductive effect of uremic toxins on the expression of proinflammatory molecules by endothelial cells, such as monocyte chemoattractant protein-1 (MCP-1) and E-selectin [101-103]. Probenecid also inhibited the osteogenic differentiation of vascular smooth muscle cells (VSMCs) exposed to PCS [102]. IS-induced damage to osteoclasts and osteoblasts, such as apoptosis and dysfunction, was attenuated with probenecid [104,105]. IS promotes oxidative stress, cytokine expression, and atrophy in skeletal muscle cells, but these effects are reversed with probenecid [106]. All these data support the involvement of OATs in the entry of uremic toxins, such as PCS and IS, into the cell.

More recently, studies using animal models have investigated the use of drugs that inhibit OATs and their effect on uremic toxins levels, especially in the context of kidney disease. Luo et al. (2020) demonstrated that probenecid and ciprofloxacin reduced IS renal clearance by $89 \%$ and $71 \%$, respectively, in rats treated with this uremic toxin [107]. Ciprofloxacin is an antibiotic that is related to the inhibition of OAT3-mediated transport $[107,108]$. In another study with an animal model, Li et al. (2021) observed that furosemide inhibited renal clearance of TMAO, increasing its plasma and kidney levels [109]. Studies have shown that furosemide, a diuretic drug, interacts with OATs and cell efflux transporters such as BCRP and MRP2 [89,109,110]. 
The accumulation of uremic toxins with the use of OATs inhibitors is also observed in humans. Granados et al. (2021) verified that a cohort of 20 human subjects treated with probenecid had elevated levels of tryptophan-derived metabolites, including IS and kynurenine [111]. In a cohort of kidney transplant patients, André et al. (2022) demonstrated that patients with a prescription of at least one drug which inhibits OAT1/OAT3 $(n=311)$ had higher plasma levels of IS, PCS, and IAA, but no difference in TMAO levels compared to patients without a prescription of OAT inhibitors $(n=92)$ [112]. The authors also showed a significant accumulation of PCS in patients with OAT-inhibiting drug prescriptions than in those without, even adjusting parameters for age, renal function, transplant time, and plasma albumin levels by multivariate analysis [112]. Together, these data indicate that drug pharmacokinetics may affect the transport of uremic toxins involving OATs, which highlights the need to understand the interaction of transporters with these drugs and the uremic toxins, especially in CKD.

OAT2 is another isoform of this protein family related to the uptake of uremic toxin creatinine. Renal clearance of creatinine is performed by glomerular filtration as well as tubular secretion, in which OAT2 participates together with other transporters $[113,114]$. OAT2 is encoded by the SLC22A7 gene and is expressed in the kidneys and liver [77]. However, the transport of uremic toxins by other OATs is still unclear.

\subsection{Organic Cation Transporters (OCTs)}

Organic cation transporters (OCTs) are polyspecific transporters that mainly have cationic compounds as substrate, but they can transport other molecules depending on their properties $[115,116]$. Like OATs, OCTs also belong to the SLC22A family. The group presents the OCT1-3 isoforms, which are characterized by having from 540 to 560 amino acids in 12 transmembrane domains and several glycosylation and phosphorylation sites. The transport mechanism of OCT substrates is based on diffusion facilitated by electrogenic uniporters or as cation exchangers $[115,117]$.

OCT2 is encoded by the SLC22A2 gene and is related to the transport of uremic toxins, especially those from the group of guanidine compounds [116,118-120]. This transporter is found in the basolateral membrane of renal tubule cells, participating in the renal clearance of several endogenous and exogenous compounds [82,121]. Likewise, OCTs can interact with multiple drugs. For example, metformin is a drug widely used in diabetes treatment and a known substrate of OCT2 [122]. Cheung et al. (2017) investigated the interaction of OCT2 with 72 uremic solutes and identified that creatinine, dimethylamine, malondialdehyde, trimethylamine, homocysteine, indoxyl- $\beta$-D-glucuronide, and glutathione disulfide inhibited $\left[{ }^{14} \mathrm{C}\right]$-labeled metformin uptake by OCT2, suggesting some type of interaction between these compounds and the transporter [123].

In vitro studies have also shown that creatinine, methylguanidine, guanidine, putrescine, and TMAO uremic toxins are substrates of OCT2 [110,116,118,124,125]. An approximately two-fold increase in plasma TMAO concentrations was observed in mice with double knockout of Oct1 and Oct2 compared to the control group $[110,126]$. Furthermore, the ratio between TMAO levels in kidneys and plasma were lower in mice with the Oct1/Oct2 knockout compared to the control group, but no difference was found in the ratio of TMAO levels in liver and plasma [110]. As Oct1 is expressed in the liver and Oct2 in the kidneys, these data indicate that Oct2 has an important role in the renal elimination of TMAO [110].

The interaction between drugs and OCT2 may influence the transport of uremic toxins. Studies have shown that serum creatinine levels may be increased with the use of drugs that compete for OCT2, impairing the tubular secretion of this uremic toxin $[117,127]$. Ciarimboli et al. (2012) reported that cancer patients undergoing treatment with cisplatin, also an OCT2 substrate, had elevated serum creatinine levels [128]. It was recently shown that the drug vandetanib inhibited cellular uptake of creatinine by OCT2 using mechanisms that are still unclear [129]. 
OCT2 expression in the kidneys is reduced in CKD. Studies with nephrectomized rats have shown a decrease in Oct2 levels in the kidneys [85,130]. However, Ji et al. (2002) demonstrated that Oct2 levels were restored in nephrectomized rats with the administration of testosterone, which regulates its expression [85]. Recently, Han et al. (2022) reported reduced levels of OCT2 in renal biopsies of patients with CKD [130]. In addition, polymorphisms in OCT2 gene encoding and changes in its expression may also influence the renal clearance via this transporter. Genomic studies have identified several single nucleotide polymorphisms (SNP) in intergenic or coding regions that are associated with OCT2 activity [128,131-133].

The transport capacity of uremic toxins related to other OCT isoforms is still unclear. OCT1 is encoded by the SLC22A1 gene, is mainly found in the basolateral membrane of hepatocytes and may be involved in the uptake of guanidinovaleric acid [77,118]. On the other hand, OCT3 is encoded by the SLC22A3 gene and widely distributed by tissues, including skeletal muscle, placenta, kidney, and epithelial cells of choroid plexus [77]. Although OCT3 is also found in the kidneys, its levels are lower than OCT2 [77,121]. However, OCT3 in the choroid plexus is related to the cellular uptake of creatinine and at least partly contributes to the removal of this uremic toxin from the cerebrospinal fluid [134].

\subsection{Organic Anion-Transporting Polypeptides (OATPS)}

Organic anion-transporting polypeptides (OATPs) belong to the organic solute carrier (SLCO) gene family, which is within the SLC superfamily. This group is characterized by mainly transporting amphipathic organic anions, including compounds larger than 300 $\mathrm{Da}$, but they may also have neutral and positively charged molecules as substrates [79]. The structure of OATPs has 650 to 700 amino acids distributed in 12 transmembrane domains with post-translational modification sites and $\mathrm{NH}_{2}$ and $\mathrm{COOH}$ terminations in the cytoplasmic space [135]. Eleven isoforms of OATPs have been identified in human tissues with a wide variety of substrates, including endogenous compounds, toxins, and drugs [136].

OATP4C1 is encoded by the SLCO4C1 gene and is highlighted by interacting with some uremic toxins and having its expression altered in CKD. This transporter is mainly found in the kidneys, in which it participates in excreting several molecules [77]. OATP4C1 mediates the cellular uptake of asymmetric dimethylarginine (ADMA), a uremic toxin known to contribute to endothelial dysfunction and CVD development in patients with CKD [137-141]. In vitro, Toyohara et al. (2009) observed that mice with transgenic-induced OATP4C1 expression in the kidneys showed a decrease in plasma levels of ADMA, suggesting that this transporter is involved in ADMA uptake [142]. Interestingly, nephrectomized rats treated with pravastatin, a drug from the statin group, had an increase in both OATP4C1 levels in the kidney and ADMA renal clearance [142]. In contrast, Akiyama et al. (2013) demonstrated that IS downregulated OATP4C1 expression in renal cells [143]. A reduction in OATP4C1 levels in the kidneys of rats treated with IS for 4 weeks compared to the control group was observed in vitro. This same study also demonstrated that rats treated with IS had an increase in serum guanidinosuccinate levels, an OATP4C1 substrate, but not of creatinine or ADMA [143]. Similarly, a decrease in OATP4C1 expression was observed in the kidneys of nephrectomized animals [144]. These data suggest that modulation of OATP4C1 expression by drugs may not only influence the transport of uremic toxins, but uremic toxins can also modulate the transporter expression.

Uremic toxins can also affect the expression and activity of OATPs present in the liver and, therefore, influence the metabolism of other compounds, including drugs. This is the case of OATP1B1 and OATP1B3, encoded by the SLCO1B1 and SLCO1B3 genes, respectively. Both transporters had their expression reduced in hepatocytes exposed to uremic plasma from patients with CKD [145]. The transporters also had their activity inhibited in the presence of the uremic toxin mix that included IS, indole acetate, hippuric acid, and CMPF [145]. The downregulation and inhibition of OATP1B1 and OATP1B3 with 
renal failure may impair the uptake and elimination of drugs that use these transporters, such as 7-Ethyl-10-hydroxycamptothecin (SN-38), used in cancer treatment $[145,146]$.

\subsection{Inorganic Phosphate Transporters (PiTs)}

Type-III sodium-dependent phosphate transporters 1 and 2 (PiT-1 and PiT-2) are encoded by the SLC20A1 and SLC20A2 genes, respectively, part of the SLC20 gene family. PiTs structurally contain 12 transmembrane domains, with both $\mathrm{NH}_{2}$ and $\mathrm{COOH}$ terminations in the extracellular space, with transport based on the $\mathrm{Na}^{+}$concentration gradient to translocate $\mathrm{Pi}[147,148]$. Both transporters are related to Pi cellular uptake, with broad tissue distribution $[148,149]$. Studies suggest that PiTs are important for homeostasis but may also participate in pathological processes in response to hyperphosphatemia conditions [150,151].

Patients with CKD develop hyperphosphatemia, especially in the more advanced stages, which is related to several comorbidities in these patients [152]. Hyperphosphatemia conditions impair vascular functions, a process in which PiTs may play an important role [151,153,154]. Abbasian et al. (2015) demonstrated an increase in intracellular Pi concentrations in endothelial cells when the cells were exposed to hyperphosphatemia conditions, which was related to uptake by PiTs [154]. The study also showed that this effect was reversed with the inhibition and knockout of PiT-1 [154]. High Pi levels induced osteochondrogenic differentiation in VSMCs and matrix mineralization via PiT-1, which contributes to vascular calcification $[151,155,156]$.

Another important Pi transporter is $\mathrm{NaPi} 2 \mathrm{~B}$ which is encoded by the SLC $34 A 2$ gene, part of the SLC34 family. This transporter is responsible for the uptake of Pi in the intestine [148]. Nicotinic acid and nicotinamide are compounds that inhibit NaPi2B expression, reducing the intestinal absorption of $\mathrm{Pi}$ [157]. However, clinical and in vivo studies with these compounds have indicated a modest reduction in serum Pi levels and several adverse effects [152].

A synthesis of in vitro, animal, and clinical studies that link uremic toxins with cellular influx transporters, especially in CKD, is presented in Table 2.

Table 2. Studies that address the relationship between cellular influx transporters and uremic toxins in chronic kidney disease.

\begin{tabular}{|c|c|c|}
\hline Protein & Experimental Model & Main Findings \\
\hline \multirow{9}{*}{ OAT1 } & OAT1-expressing HEK293 cells & Cell uptake of PCS [100] \\
\hline & Slc22a6-knockout mice & Increased plasma levels of PCS, IS, and kynurenine [89] \\
\hline & Slc22a6-knockout mice & Increased plasma levels of PCS, IS, and IAA [88] \\
\hline & Rats & Renal uptake of hippurate, IAA, and IS [92] \\
\hline & Nephrectomized rats & Decreased protein levels in the kidneys [83] \\
\hline & Nephrectomized rats & Decreased protein and mRNA levels in the kidneys [84] \\
\hline & Nephrectomized rats & Decreased protein levels in the kidneys [86] \\
\hline & Nephrectomized rats & No differences in protein levels in the kidney [85] \\
\hline & Nephrectomized rats treated with IS & Increased protein levels in the renal tubules [87] \\
\hline \multirow{5}{*}{ OAT3 } & OAT3-expressing HEK293 cells & Cell uptake of PCS [100] \\
\hline & Rats and Oat3-expressing oocytes & Renal uptake of IS [94] \\
\hline & Slc22a8-knockout mice & Increased plasma levels of PCS, IS, CMPF, and TMAO [89] \\
\hline & Rats & Renal uptake of IS and CMPF [92] \\
\hline & Rats treated with IS & $\begin{array}{l}\text { Decreased the renal clearance of IS through inhibition on the } \\
\text { OAT3-mediated transport with ciprofloxacin [107] }\end{array}$ \\
\hline
\end{tabular}


Table 2. Cont.

\begin{tabular}{|c|c|c|}
\hline Protein & Experimental Model & Main Findings \\
\hline \multirow{2}{*}{ OAT3 } & Nephrectomized rats & Decreased protein levels in the kidneys [86] \\
\hline & Nephrectomized rats & No differences in protein levels in the kidney [85] \\
\hline \multirow{8}{*}{ OAT1/3 } & HK-2 cells and rat renal cortical slices & $\begin{array}{l}\text { Cell uptake of PCS, which was inhibited with probenecid, an } \\
\text { inhibitor of OATs [93] }\end{array}$ \\
\hline & Endothelial cells & $\begin{array}{l}\text { Cell uptake of PCS and IS, which was inhibited with } \\
\text { probenecid [101] }\end{array}$ \\
\hline & Endothelial cells & $\begin{array}{l}\text { Probenecid attenuated the inductive effects of IS on the expression } \\
\text { of E-selectin and monocytic cell adhesion [103] }\end{array}$ \\
\hline & $\begin{array}{l}\text { Endothelial cells and aortic smooth } \\
\text { muscle cells }\end{array}$ & $\begin{array}{l}\text { Probenecid reversed the inductive effect of PCS on MCP-1 } \\
\text { expression in endothelial cells and on the expression of osteogenic } \\
\text { differentiation genes in aortic smooth muscle cells [102] }\end{array}$ \\
\hline & Osteoblasts & $\begin{array}{l}\text { Probenecid restored IS-induced effects on cell viability and ROS } \\
\text { levels [104] }\end{array}$ \\
\hline & Myoblast cells & $\begin{array}{c}\text { Probenecid reversed IS-induced effects on ROS levels and } \\
\text { inflammatory cytokine expression [106] }\end{array}$ \\
\hline & Human subjects & $\begin{array}{l}\text { Subjects treated with probenecid had elevated IS and kynurenine } \\
\text { levels [111] }\end{array}$ \\
\hline & Kidney transplant patients & $\begin{array}{l}\text { Increased plasma levels of IS, PCS and IAA in patients with a } \\
\text { prescription of at least one drug which inhibits OAT1/OAT3 [112] }\end{array}$ \\
\hline \multirow{2}{*}{ OAT2 } & MDCKII cells & Cell uptake of creatinine [113] \\
\hline & OAT2-transfected HEK cells & Cell uptake of creatinine [114] \\
\hline \multirow{13}{*}{ OCT2 } & ciPTEC cells & $\begin{array}{l}\text { Uptake of cationic uremic toxins, such as guanidine, } \\
\text { methylguanidine, and putrescine [116] }\end{array}$ \\
\hline & HEK293 cells & Cell uptake of guanidine compounds [118] \\
\hline & HEK293 cells & Cell uptake of creatinine [120] \\
\hline & MDCKII and HEK cells & Cell uptake of TMAO and transcellular transport [125] \\
\hline & HEK293 cells & Cell uptake of putrescine [124] \\
\hline & OCT2-expressing HEK cells & $\begin{array}{c}\text { Inhibited by creatinine, dimethylamine, malondialdehyde, } \\
\text { trimethylamine, homocysteine, indoxyl- } \beta \text {-D-glucuronide, and } \\
\text { glutathione disulfide [123] }\end{array}$ \\
\hline & HEK293 cells & Vandetanib inhibited the uptake of creatinine [129] \\
\hline & $\begin{array}{l}\text { Slc22a2/1-double knockout mice and } \\
\text { HeLa cells }\end{array}$ & Increased plasma levels of TMAO. In vitro, TMAO transport [110] \\
\hline & $\begin{array}{l}\text { Slc22a2/1-double knockout mice and } \\
\text { Oct2-transfected HEK293 cells }\end{array}$ & $\begin{array}{l}\text { Increased plasma levels of TMAO. In vitro and In vitro, TMAO } \\
\text { uptake [126] }\end{array}$ \\
\hline & Nephrectomized rats & Decreased protein levels in the kidney [85] \\
\hline & Patients with CKD and nephrectomized rats & Decreased protein levels in the kidney [130] \\
\hline & $\begin{array}{l}\text { Patients with cancer undergoing treatment } \\
\text { with cisplatin and HEK293 cells }\end{array}$ & $\begin{array}{l}\text { Increased serum levels of creatinine. In vitro, creatinine } \\
\text { uptake [128] }\end{array}$ \\
\hline & Patients with end-stage renal disease & $\begin{array}{c}\text { Relationship between } S L C 22 A 2 \text { polymorphisms and phenotypes of } \\
\text { net tubular creatinine secretion [119] }\end{array}$ \\
\hline \multirow{3}{*}{ OATP4C1 } & MDCK cells & Transport of ADMA [141] \\
\hline & HEK293 cells & Cell uptake of ADMA [140] \\
\hline & HK-2 cells and rats treated with IS & IS reduced the OATP4C1 expression [143] \\
\hline
\end{tabular}


Table 2. Cont.

\begin{tabular}{|c|c|c|}
\hline Protein & Experimental Model & Main Findings \\
\hline \multirow[t]{2}{*}{ OATP4C1 } & $\begin{array}{l}\text { Transgenic mice overexpressing OATP4C } 1 \text { in } \\
\text { the kidneys }\end{array}$ & $\begin{array}{l}\text { Decreased plasma levels of ADMA, guanidino succinate, and } \\
\text { trans-aconitate [142] }\end{array}$ \\
\hline & Nephrectomized rats & Decreased mRNA levels in the kidney [144] \\
\hline OATP1B1/3 & Human hepatocytes and HEK293 cells & $\begin{array}{l}\text { Decreased mRNA levels in cells exposed to uremic plasma. } \\
\text { Inhibited by uremic toxin mix (IS, indole acetate, hippuric acid, and } \\
\text { CMPF) [145] }\end{array}$ \\
\hline \multirow{4}{*}{ PiT-1/2 } & Endothelial cells & $\begin{array}{c}\text { Inhibition and knockout of PiT-1 reduced intracellular Pi } \\
\text { concentrations [154] }\end{array}$ \\
\hline & PiT-1-expressing oocytes & Pi transport [150] \\
\hline & VSMCs & $\begin{array}{l}\text { Uptake of Pi, which at high levels induces osteochondrogenic } \\
\text { differentiation of VSMCs [155] }\end{array}$ \\
\hline & Human smooth muscle cells & Cell uptake of $\mathrm{Pi}[156]$ \\
\hline & $\begin{array}{l}\text { Abbreviations: ADMA, asymme } \\
\text { CMPF, 3-Carboxy-4-methyl-5-pr } \\
\text { proximal tubular cells; IAA, indo } \\
\text { MDCKII, Madin-Darby canine ki } \\
\text { species; TMAO, trimethylamine- }\end{array}$ & $\begin{array}{l}\text { c dimethylarginine; ciPTEC, immortalized proximal tubule epithelial cells } \\
\text { yl-2-furanpropionate; HEK, human embryonic kidney cells; HK-2, humar } \\
\text {-acetic acid; IS, indoxyl sulfate; MCP-1, monocyte chemoattractant protein-1 } \\
\text { ey II cells; PCS, p-cresyl sulfate; Pi, inorganic phosphate; ROS, reactive oxyger } \\
\text { oxide; VSMCs, vascular smooth muscle cells. }\end{array}$ \\
\hline
\end{tabular}

\subsection{Multidrug and Toxin Extrusion (MATE)}

Multidrug and toxin extrusion (MATEs) are membrane proteins which are part of the SLC47 family, which is included in the SLC superfamily. The main representatives are MATE1 and MATE2-K, encoded by the SLC47A1 and SLC47A2 genes, respectively. Both mediate the cellular efflux of various compounds, particularly organic cations, presenting a large overlap with OCT substrates [158,159]. Basically, the transport mechanism of MATEs is antiport with the exchange of protons and organic cations [159]. MATE1 and MATE2-K are mainly expressed in the kidneys, but MATE1 can also be found in the liver, adrenal gland, heart, and others [82,160]. MATE1 and MATE2-K are found in the apical membrane of renal cells in the kidneys and are important for tubular secretion [82].

MATEs are related to the mediated transport of both uremic toxins and various drugs used in clinical treatments. Studies have shown that both MATE1 and MATE2-K have creatinine and guanidines as substrates [159,161]. Gessner et al. (2018) investigated TMAO cell efflux via MATE1 using polarized monolayers of canine kidney cells (MDCK cells) [125]. The authors reported greater translocation of TMAO from the basal to the apical region in cells expressing MATE1 or MATE1 in conjunction with OCT2 [125]. It was also observed that trimethoprim, an antibiotic inhibitor of OCTs and MATEs, suppressed TMAO translocation in cells expressing both OCT and MATE1 [125]. Other drugs are also known to interact with MATE1, such as trospium and ondansetron [162,163]. Cimetidin and metformin are other examples of drugs that are substrates for both MATE1 and MATE2$\mathrm{K}$ [159]. However, the use of drugs that compete for MATEs and their impact on uremic toxin levels is still unclear. Furthermore, the expression of MATEs may be altered under pathological conditions. Nephrectomized rats showed a reduction in Mate1 protein levels in both males and females [164].

\subsection{Breast Cancer Resistance Protein (BCRP)}

Breast cancer resistance protein (BCRP) is encoded by the $A B C G 2$ gene and forms homodimers in the cell membrane to efflux a wide variety of substrates, including uremic toxins [165]. BCRP belongs to the ABCG family, part of the ABC superfamily. This protein has 655 amino acids organized into six $\alpha$-helices and a nucleotide-binding domain located at the $\mathrm{NH}_{2}$ termination in the cytoplasm [166,167]. Like other members of the ABC superfamily, its activity is dependent on ATP hydrolysis [166,167]. BCRP is found expressed in the kidney, intestine, liver, placenta, and blood vessels [168-171]. However, studies 
have reported a decrease in Bcrp expression in the kidneys of nephrectomized animals compared to the sham group, demonstrating that CKD may alter the expression of this transporter [172,173].

$\mathrm{BCRP}$ is widely known for its drug transport, being primarily related to the pharmacokinetics of drugs used in cancer therapies. In recent years, BCRP has been shown to interact with several uremic toxins, especially in the transport of these compounds from the intracellular compartment to the renal lumen in the tubular secretion process. Mutsaers et al. (2015) demonstrated that BCRP inhibition with KO143 leads to increased intracellular PCS levels, indicating that this uremic toxin is a substrate for the transporter [174]. In

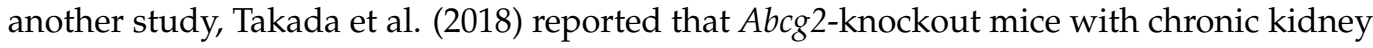
dysfunction had high plasma levels as well as low renal clearance of IS compared to the control group, suggesting that BCRP is essential for renal elimination of this uremic toxin [175]. It was recently shown that BCRP inhibition with the uricosuric agent febuxostat resulted in decreased renal clearance of the IS [97]. Other studies using an in vitro model also suggest that IS, kynurenic acid, TMAO, and uric acid are BCRP substrates [110,175-179]. In addition, IS increased the expression of BCRP in intestinal cells, also resulting in greater translocation of urate from the basolateral to the apical compartments [179]. In fact, BCRP is an important uric acid transporter, contributing to the excretion of this uremic toxin by both the renal and intestinal routes. The increased plasma uric acid levels in patients with hyperuricemia may be correlated with polymorphisms in the ABCG2 gene [180-182]. Other cells that express BCPR are also affected by uric acid. Komori et al. (2018) reported that uric acid reduced the protein levels of BCRP in the membrane of endothelial cells, resulting in lower efflux and increased intracellular concentrations of this uremic toxin [183].

\subsection{Multidrug Resistance-Associated Proteins (MRPs)}

Multidrug resistance-associated proteins (MRPs) are cell efflux transporters that interact with a wide variety of substrates. MRPs are part of the ABCC gene family which belongs to the ABC superfamily, characterized by ATP hydrolysis-dependent activity. The main members of this group are MRP2 and MRP4 encoded by the ABCC2 and ABCC4 genes, respectively. Both transporters are found in the apical membrane of proximal tubule cells, participating in the tubular secretion of endogenous and exogenous compounds. Moreover, MRP2 and MRP4 are also found in the liver, intestine, and brain capillary endothelium [168,184-187]. MRP2 expression increased in the kidneys and liver in a CKD animal model, while it decreased in the intestine $[84,172,188]$. On the other hand, MRP4 expression in nephrectomized animals did not change in the liver and intestine, while it is controversial in the kidneys, with studies indicating that it increases or does not change $[84,172,189]$.

Although MRPs are considered potential transporters for uremic toxins, this interaction has been little explored. Mutsaers et al. (2011) observed that MRP4 activity is inhibited in the presence of IS, hippuric acid, kynurenic acid, IAA, and phenylacetic acid, which may suggest an interaction between these uremic toxins and the transporter [178]. In another study, Mutsaers et al. (2015) demonstrated that MRP4 activity was inhibited by PCS and $p$-cresyl glucuronide; however, the uptake of these toxins in vesicles expressing MRP4 was not observed [174]. In addition, Teft et al. (2017) showed that MRP2 and MRP4 participate in TMAO cell efflux in an in vitro model [110]. Like other transporters, MRP2 and MRP4 also have drugs as substrates, such as methotrexate [190]. Furthermore, studies have shown that several nonsteroidal anti-inflammatory drugs inhibited MRPs activity [190-192]. Therefore, more studies are needed to understand how the cellular efflux of uremic toxins occurs and its potential relationship with the use of prescribed drugs.

The main findings from in vitro and animal studies that investigated uremic toxins and their relationship to cellular efflux transporters are listed in Table 3. 
Table 3. Studies that address the relationship between cellular efflux transporters and uremic toxins in chronic kidney disease.

\begin{tabular}{|c|c|c|}
\hline Protein & Experimental Model & Main Findings \\
\hline \multirow{4}{*}{ MATE1 } & HEK293 cells & Creatinine and guanidine as substrates [159] \\
\hline & HEK293 cells & Creatinine as substrate [161] \\
\hline & MDCKII and HEK cells & Transport of TMAO, which was suppressed by trimethoprim [125] \\
\hline & Nephrectomized rats & Decreased protein levels in the kidneys [164] \\
\hline MATE2-K & HEK293 cells & Creatinine and guanidine as substrates [159] \\
\hline \multirow{11}{*}{ BCRP } & ciPTEC cells & BCRP inhibition increased intracellular PCS levels [174] \\
\hline & HeLa cells & TMAO transport [110] \\
\hline & $\begin{array}{l}\text { Membrane vesicles from } \\
\text { MRP4-overexpressing HEK cells }\end{array}$ & Inhibited by hippuric acid, IS, and kynurenic acid [178] \\
\hline & Caco-2 cells & Urate transport. IS reduced BCRP expression [179] \\
\hline & Endothelial cells & Uric acid decreased the BCRP protein levels [183] \\
\hline & $\begin{array}{c}A b c g \text { 2-knockout mice with } \\
\text { adenine-induced CKD and membrane } \\
\text { vesicles from HEK293A cells }\end{array}$ & $\begin{array}{l}\text { Increased plasma levels and decreased renal elimination of IS. In vitro, } \\
\text { IS transport [175] }\end{array}$ \\
\hline & Abcg2-knockout mice and HEK293 cells & Kynurenic acid as substrate [177] \\
\hline & Abcg2-knockout mice & Increased plasma levels and low urine levels of IS [175] \\
\hline & Adenine-induced acute renal failure rats & Febuxostat, an BCRP inhibitor, decreased renal clearance of the IS [97] \\
\hline & Nephrectomized rats & Decreased mRNA levels in the kidney [172] \\
\hline & Nephrectomized rats & Decreased protein and mRNA levels in the kidney [173] \\
\hline \multirow{4}{*}{ MRP2 } & HeLa cells & Performs cellular efflux of TMAO [110] \\
\hline & Nephrectomized rats & Increased protein and mRNA levels in the kidneys [84] \\
\hline & Nephrectomized rats & Increased mRNA levels in the liver and the kidneys [172] \\
\hline & Nephrectomized rats & Decreased protein levels in the intestine [188] \\
\hline \multirow{6}{*}{ MRP4 } & $\begin{array}{l}\text { Membrane vesicles from } \\
\text { MRP4-overexpressing HEK cells }\end{array}$ & $\begin{array}{l}\text { Inhibited by IS, hippuric acid, kynurenic acid, IAA, and phenylacetic } \\
\text { acid [178] }\end{array}$ \\
\hline & ciPTEC cells & Inhibited by PCS and $p$-cresyl glucuronide [174] \\
\hline & HeLa cells & Performs cellular efflux of TMAO [110] \\
\hline & Nephrectomized rats & Increased protein and mRNA levels in the kidneys [84] \\
\hline & Nephrectomized rats & No differences in mRNA levels in the kidney, liver, and intestine [172] \\
\hline & Nephrectomized rats & No differences in mRNA levels in the kidney and the liver [189] \\
\hline
\end{tabular}

\section{Final Considerations}

Uremic toxins are important factors contributing to the pathogenesis of $\mathrm{CKD}$, and their elimination by dialysis therapies is limited. PBUTs specifically have a high affinity for serum albumin, and their removal by dialysis is still a challenge, although some studies have explored strategies that break this interaction, including using drugs that also have an affinity for albumin. Uremic toxins reach various tissues and organs through the bloodstream. Several uremic toxins are capable of interacting with membrane transporters, mediating their entry or exit from the cell and may cause biological effects under uremic conditions, such as cell dysfunction. Membrane transporters are particularly important in renal clearance and elimination by other routes of uremic toxins and drugs. Therefore, there may be competition between toxins and drugs as substrates of the transporter or even 
inhibition of its activity. Another relevant outcome is the change in the expression of these transporters in CKD. Consequently, tissue disposition and the elimination of uremic toxins as well as drugs may be affected. Despite this, clinical studies addressing this issue are still scarce. Altogether, it is important to evaluate the interaction of drugs and uremic toxins via albumin or transporters and their impact on the clinical course of patients with CKD. In addition, studies in this area could contribute to the development of new therapeutic strategies to improve the removal of uremic toxins by dialysis.

Author Contributions: R.S.d.C., C.A.B.A., C.A.F., F.F.R., S.L. and M.S.C.-R. wrote the manuscript. R.S.d.C. made the figures. A.E.M.S. and M.S.C.-R. edited and reviewed the manuscript. All authors have read and agreed to the published version of the manuscript.

Funding: The authors acknowledge the support from the Coordenação de Aperfeiçoamento de Pessoal de Nivel Superior-Brasil (CAPES)—Finance Code 001 and the São Paulo Research Foundation (FAPESP) grant 2019/11077-0.

Conflicts of Interest: The authors declare no conflict of interest.

\section{References}

1. Vanholder, R.; De Smet, R.; Glorieux, G.; Argilés, A.; Baurmeister, U.; Brunet, P.; Clark, W.; Cohen, G.; De Deyn, P.P.; Deppisch, R.; et al. Review on uremic toxins: Classification, concentration, and interindividual variability. Kidney Int. 2003, 63, $1934-1943$. [CrossRef] [PubMed]

2. Falconi, C.A.; da Cruz Junho, C.V.; Fogaça-Ruiz, F.; Vernier, I.C.S.; da Cunha, R.S.; Stinghen, A.E.M.; Carneiro-Ramos, M.S. Uremic Toxins: An Alarming Danger Concerning the Cardiovascular System. Front. Physiol. 2021, 12, 114460. [CrossRef]

3. Li, X.S.; Obeid, S.; Klingenberg, R.; Gencer, B.; Mach, F.; Räber, L.; Windecker, S.; Rodondi, N.; Nanchen, D.; Muller, O.; et al. Gutmicrobiota-dependent trimethylamine $N$-oxide in acute coronary syndromes: A prognostic marker for incident cardiovascular events beyond traditional risk factors. Eur. Heart J. 2017, 38, 814-824. [CrossRef]

4. Stubbs, J.R.; House, J.A.; Ocque, A.J.; Zhang, S.; Johnson, C.; Kimber, C.; Schmidt, K.; Gupta, A.; Wetmore, J.B.; Nolin, T.D.; et al. Serum Trimethylamine-N-Oxide is Elevated in CKD and Correlates with Coronary Atherosclerosis Burden. J. Am. Soc. Nephrol. 2016, 27, 305-313. [CrossRef]

5. Barreto, F.C.; Stinghen, A.E.M.; De Oliveira, R.B.; Franco, A.T.B.; Moreno, A.N.; Barreto, D.V.; Pecoits-Filho, R.; Drüeke, T.B.; Massy, Z.A. The quest for a better understanding of chronic kidney disease complications: An update on uremic toxins. J. Bras. Nefrol. 2014, 36, 221-235. [CrossRef]

6. Massy, Z.A.; Liabeuf, S. Middle-molecule uremic toxins and outcomes in chronic kidney disease. Contrib. Nephrol. 2017, 191, 8-17. [CrossRef]

7. Van Gelder, M.K.; Middel, I.R.; Vernooij, R.W.M.; Bots, M.L.; Verhaar, M.C.; Masereeuw, R.; Grooteman, M.P.; Nubé, M.J.; van den Dorpel, M.A.; Blankestijn, P.J.; et al. Protein-Bound Uremic Toxins in Hemodialysis Patients Relate to Residual Kidney Function, Are Not Influenced by Convective Transport, and Do Not Relate to Outcome. Toxins 2020, 12, 234. [CrossRef]

8. Han, H.; Zhu, J.; Zhu, Z.; Ni, J.; Du, R.; Dai, Y.; Chen, Y.; Wu, Z.; Lu, L.; Zhang, R. p-Cresyl Sulfate Aggravates Cardiac Dysfunction Associated with Chronic Kidney Disease by Enhancing Apoptosis of Cardiomyocytes. J. Am. Heart Assoc. 2015, 4, e001852. [CrossRef]

9. Calaf, R.; Cerini, C.; Génovésio, C.; Verhaeghe, P.; Jourde-Chiche, N.; Bergé-Lefranc, D.; Gondouin, B.; Dou, L.; Morange, S.; Argilés, A.; et al. Determination of uremic solutes in biological fluids of chronic kidney disease patients by HPLC assay. J. Chromatogr. B 2011, 879, 2281-2286. [CrossRef]

10. Niwa, T. Uremic toxicity of indoxyl sulfate. Nagoya J. Med. Sci. 2010, 72, 1-11.

11. Ito, S.; Yoshida, M. Protein-bound uremic toxins: New culprits of cardiovascular events in chronic kidney disease patients. Toxins 2014, 6, 665-678. [CrossRef]

12. Barreto, F.C.; Barreto, D.V.; Liabeuf, S.; Meert, N.; Glorieux, G.; Temmar, M.; Choukroun, G.; Vanholder, R.; Massy, Z.A. Serum Indoxyl Sulfate Is Associated with Vascular Disease and Mortality in Chronic Kidney Disease Patients. Clin. J. Am. Soc. Nephrol. 2009, 4, 1551-1558. [CrossRef]

13. Lekawanvijit, S. Cardiotoxicity of uremic toxins: A driver of cardiorenal syndrome. Toxins 2018, 10, 352. [CrossRef]

14. Gao, H.; Liu, S. Role of uremic toxin indoxyl sulfate in the progression of cardiovascular disease. Life Sci. 2017, 185, 23-29. [CrossRef]

15. Da Cunha, R.S.; Santos, A.F.; Barreto, F.C.; Stinghen, A.E.M. How do Uremic Toxins Affect the Endothelium? Toxins 2020, $12,412$. [CrossRef]

16. Lekawanvijit, S.; Adrahtas, A.; Kelly, D.J.; Kompa, A.R.; Wang, B.H.; Krum, H. Does indoxyl sulfate, a uraemic toxin, have direct effects on cardiac fibroblasts and myocytes? Eur. Heart J. 2010, 31, 1771-1779. [CrossRef]

17. Kim, H.Y.; Yoo, T.-H.; Cho, J.-Y.; Kim, H.C.; Lee, W.-W. Indoxyl sulfate-induced TNF- $\alpha$ is regulated by crosstalk between the aryl hydrocarbon receptor, NF-kB, and SOCS2 in human macrophages. FASEB J. 2019, 33, 10844-10858. [CrossRef] 
18. Yang, K.; Wang, C.; Nie, L.; Zhao, X.; Gu, J.; Guan, X.; Wang, S.; Xiao, T.; Xu, X.; He, T.; et al. Klotho Protects Against Indoxyl Sulphate-Induced Myocardial Hypertrophy. J. Am. Soc. Nephrol. 2015, 26, 2434-2446. [CrossRef]

19. Nakano, T.; Katsuki, S.; Chen, M.; Decano, J.L.; Halu, A.; Lee, L.H.; Pestana, D.V.S.; Kum, A.S.T.; Kuromoto, R.K.; Golden, W.S.; et al. Uremic Toxin Indoxyl Sulfate Promotes Proinflammatory Macrophage Activation Via the Interplay of OATP2B1 and Dll4-Notch Signaling. Circulation 2019, 139, 78-96. [CrossRef]

20. Gryp, T.; Vanholder, R.; Vaneechoutte, M.; Glorieux, G. p-Cresyl Sulfate. Toxins 2017, 9, 52. [CrossRef]

21. Vanholder, R.; Schepers, E.; Pletinck, A.; Nagler, E.V.; Glorieux, G. The Uremic Toxicity of Indoxyl Sulfate and p-Cresyl Sulfate: A Systematic Review. J. Am. Soc. Nephrol. 2014, 25, 1897-1907. [CrossRef]

22. Gondouin, B.; Cerini, C.; Dou, L.; Sallée, M.; Duval-Sabatier, A.; Pletinck, A.; Calaf, R.; Lacroix, R.; Jourde-Chiche, N.; Poitevin, S.; et al. Indolic uremic solutes increase tissue factor production in endothelial cells by the aryl hydrocarbon receptor pathway. Kidney Int. 2013, 84, 733-744. [CrossRef]

23. Edamatsu, T.; Fujieda, A.; Itoh, Y. Phenyl sulfate, indoxyl sulfate and p-cresyl sulfate decrease glutathione level to render cells vulnerable to oxidative stress in renal tubular cells. PLOS ONE 2018, 13, e0193342. [CrossRef]

24. Huang, T.H.; Yip, H.K.; Sun, C.K.; Chen, Y.L.; Yang, C.C.; Lee, F.Y. P-cresyl sulfate causes mitochondrial hyperfusion in H9C2 cardiomyoblasts. J. Cell. Mol. Med. 2020, 24, 8379-8390. [CrossRef]

25. Glorieux, G.; Vanholder, R.; Van Biesen, W.; Pletinck, A.; Schepers, E.; Neirynck, N.; Speeckaert, M.; De Bacquer, D.; Verbeke, F. Free p-cresyl sulfate shows the highest association with cardiovascular outcome in chronic kidney disease. Nephrol. Dial. Transplant. 2021, 36, 998-1005. [CrossRef]

26. Liabeuf, S.; Laville, S.M.; Glorieux, G.; Cheddani, L.; Brazier, F.; Beauport, D.T.; Valholder, R.; Choukroun, G.; Massy, Z.A Difference in profiles of the gut-derived tryptophan metabolite indole acetic acid between transplanted and non-transplanted patients with chronic kidney disease. Int. J. Mol. Sci. 2020, 21, 2031. [CrossRef]

27. Rysz, J.; Franczyk, B.; Ławiński, J.; Olszewski, R.; Ciałkowska-Rysz, A.; Gluba-Brzózka, A. The Impact of CKD on Uremic Toxins and Gut Microbiota. Toxins 2021, 13, 252. [CrossRef]

28. Dou, L.; Poitevin, S.; Sallée, M.; Addi, T.; Gondouin, B.; McKay, N.; Denison, M.S.; Jourde-Chiche, N.; Duval-Sabatier, A.; Cerini, C.; et al. Aryl hydrocarbon receptor is activated in patients and mice with chronic kidney disease. Kidney Int. 2018, 93, 986-999. [CrossRef]

29. Dou, L.; Sallée, M.; Cerini, C.; Poitevin, S.; Gondouin, B.; Jourde-Chiche, N.; Fallague, K.; Brunet, P.; Calaf, R.; Dussol, B.; et al The cardiovascular effect of the uremic solute indole-3 acetic acid. J. Am. Soc. Nephrol. 2015, 26, 876-887. [CrossRef]

30. Lamas, B.; Natividad, J.M.; Sokol, H. Aryl hydrocarbon receptor and intestinal immunity. Mucosal Immunol. 2018, 11, 1024-1038. [CrossRef]

31. Satoh, M.; Hayashi, H.; Watanabe, M.; Ueda, K.; Yamato, H.; Yoshioka, T.; Motojima, M. Uremic Toxins Overload Accelerates Renal Damage in a Rat Model of Chronic Renal Failure. Nephron Exp. Nephrol. 2003, 95, e111-e118. [CrossRef] [PubMed]

32. Meijers, B.K.I.; Bammens, B.; Verbeke, K.; Evenepoel, P. A review of albumin binding in CKD. Am. J. Kidney Dis. 2008, 51, 839-850. [CrossRef] [PubMed]

33. Sakai, T.; Takadate, A.; Otagiri, M. Characterization of Binding Site of Uremic Toxins on Human Serum Albumin. Biol. Pharm. Bull. 1995, 18, 1755-1761. [CrossRef] [PubMed]

34. Mabuchi, H.; Nakahashi, H.; Hamajima, T.; Aikawa, I.; Oka, T. The Effect of Renal Transplantation on a Major Endogenous Ligand Retained in Uremic Serum. Am. J. Kidney Dis. 1989, 13, 49-54. [CrossRef]

35. Koppe, L.; Poitout, V. CMPF: A Biomarker for Type 2 Diabetes Mellitus Progression? Trends Endocrinol. Metab. 2016, 27, 439-440. [CrossRef] [PubMed]

36. Xu, L.; Sinclair, A.J.; Faiza, M.; Li, D.; Han, X.; Yin, H.; Wang, Y. Furan fatty acids—Beneficial or harmful to health? Prog. Lipid Res. 2017, 68, 119-137. [CrossRef]

37. Prentice, K.J.; Luu, L.; Allister, E.M.; Liu, Y.; Jun, L.S.; Sloop, K.W.; Hardy, A.B.; Wei, L.; Jia, W.; Fantus, I.G.; et al. The furan fatty acid metabolite CMPF is elevated in diabetes and induces $\beta$ cell dysfunction. Cell Metab. 2014, 19, 653-666. [CrossRef]

38. Miyamoto, Y.; Iwao, Y.; Mera, K.; Watanabe, H.; Kadowaki, D.; Ishima, Y.; Chuang, V.T.G.; Sato, K.; Otagiri, M.; Maruyama, T. A uremic toxin, 3-carboxy-4-methyl-5-propyl-2-furanpropionate induces cell damage to proximal tubular cells via the generation of a radical intermediate. Biochem. Pharmacol. 2012, 84, 1207-1214. [CrossRef]

39. Wratten, M.L.; Galaris, D.; Tetta, C.; Sevanian, A. Evolution of oxidative stress and inflammation during hemodialysis and their contribution to cardiovascular disease. Antioxid. Redox Signal. 2002, 4, 935-944. [CrossRef]

40. Boelaert, J.; Lynen, F.; Glorieux, G.; Eloot, S.; Van Landschoot, M.; Waterloos, M.A.; Sandra, P.; Vanholder, R. A novel UPLC-MSMS method for simultaneous determination of seven uremic retention toxins with cardiovascular relevance in chronic kidney disease patients. Anal. Bioanal. Chem. 2013, 405, 1937-1947. [CrossRef]

41. Luce, M.; Bouchara, A.; Pastural, M.; Granjon, S.; Szelag, J.C.; Laville, M.; Arkouche, W.; Fouque, D.; Soulage, C.O.; Koppe, L. Is 3-carboxy-4-methyl-5-propyl-2-furanpropionate (CMPF) a clinically relevant uremic toxin in haemodialysis patients? Toxins 2018, 10, 205. [CrossRef] [PubMed]

42. Fanali, G.; Di Masi, A.; Trezza, V.; Marino, M.; Fasano, M.; Ascenzi, P. Human serum albumin: From bench to bedside. Mol. Asp Med. 2012, 33, 209-290. [CrossRef] [PubMed]

43. Li, S.; Tonelli, M.; Unsworth, L.D. Indoxyl and p-cresol sulfate binding with human serum albumin. Colloids Surf. A Physicochem. Eng. Asp. 2022, 635, 128042. [CrossRef] 
44. Ghuman, J.; Zunszain, P.A.; Petitpas, I.; Bhattacharya, A.A.; Otagiri, M.; Curry, S. Structural basis of the drug-binding specificity of human serum albumin. J. Mol. Biol. 2005, 353, 38-52. [CrossRef] [PubMed]

45. Ascenzi, P.; Bocedi, A.; Notari, S.; Fanali, G.; Fesce, R.; Fasano, M. Allosteric Modulation of Drug Binding to Human Serum Albumin. Mini-Rev. Med. Chem. 2006, 6, 483-489. [CrossRef] [PubMed]

46. Gundry, R.L.; Fu, Q.; Jelinek, C.A.; Van Eyk, J.E.; Cotter, R.J. Investigation of an albumin-enriched fraction of human serum and its albuminome. Proteom. Clin. Appl. 2007, 1, 73-88. [CrossRef] [PubMed]

47. Margarson, M.P.; Soni, N. Serum albumin: Touchstone or totem? Anaesthesia 1998, 53, 789-803. [CrossRef]

48. Narazaki, R.; Otagiri, M. Covalent Binding of a Bucillamine Derivative with Albumin in Sera from Healthy Subjects and Patients with Various Diseases. Pharm. Res. 1997, 14, 351-353. [CrossRef]

49. Kawakami, A.; Kubota, K.; Yamada, N.; Tagami, U.; Takehana, K.; Sonaka, I.; Suzuki, E.; Hirayama, K. Identification and characterization of oxidized human serum albumin: A slight structural change impairs its ligand-binding and antioxidant functions. FEBS J. 2006, 273, 3346-3357. [CrossRef]

50. Oettl, K.; Stauber, R.E. Physiological and pathological changes in the redox state of human serum albumin critically influence its binding properties. Br. J. Pharmacol. 2007, 151, 580-590. [CrossRef]

51. Duni, A.; Liakopoulos, V.; Roumeliotis, S.; Peschos, D.; Dounousi, E. Oxidative stress in the pathogenesis and evolution of chronic kidney disease: Untangling ariadne's thread. Int. J. Mol. Sci. 2019, 20, 3711. [CrossRef] [PubMed]

52. Anraku, M.; Yamasaki, K.; Maruyama, T.; Kragh-Hansen, U.; Otagiri, M. Effect of oxidative stress on the structure and function of human serum albumin. Pharm. Res. 2001, 18, 632-639. [CrossRef] [PubMed]

53. Himmelfarb, J.; McMonagle, E. Albumin is the major plasma protein target of oxidant stress in uremia. Kidney Int. 2001, 60, 358-363. [CrossRef] [PubMed]

54. Wratten, M.L.; Sereni, L.; Tetta, C. Oxidation of albumin is enhanced in the presence of uremic toxins. Ren. Fail. 2001, $23,563-571$. [CrossRef] [PubMed]

55. Matsuyama, Y.; Terawaki, H.; Terada, T.; Era, S. Albumin thiol oxidation and serum protein carbonyl formation are progressively enhanced with advancing stages of chronic kidney disease. Clin. Exp. Nephrol. 2009, 13, 308-315. [CrossRef] [PubMed]

56. Massy, Z.A.; Pietrement, C.; Touré, F. Reconsidering the Lack of Urea Toxicity in Dialysis Patients. Semin. Dial. 2016, 29 , 333-337. [CrossRef]

57. Jaisson, S.; Desmons, A.; Doué, M.; Gorisse, L.; Pietrement, C.; Gillery, P. Measurement of Homocitrulline, A Carbamylationderived Product, in Serum and Tissues by LC-MS/MS. Curr. Protoc. Protein Sci. 2018, 92, e56. [CrossRef]

58. Erill, S.; Calvo, R.; Carlos, R. Plasma protein carbamylation and decreased acidic drug protein binding in uremia. Clin. Pharmacol. Ther. 1980, 27, 612-618. [CrossRef]

59. Viaene, L.; Annaert, P.; de Loor, H.; Poesen, R.; Evenepoel, P.; Meijers, B. Albumin is the main plasma binding protein for indoxyl sulfate and p-cresyl sulfate. Biopharm. Drug Dispos. 2013, 34, 165-175. [CrossRef]

60. Watanabe, H.; Noguchi, T.; Miyamoto, Y.; Kadowaki, D.; Kotani, S.; Nakajima, M.; Miyamura, S.; Ishima, Y.; Otagiri, M.; Maruyama, T. Interaction between Two Sulfate-Conjugated Uremic Toxins, p-Cresyl Sulfate and Indoxyl Sulfate, during Binding with Human Serum Albumin. Drug Metab. Dispos. 2012, 40, 1423-1428. [CrossRef]

61. Meijers, B.K.I.; De Loor, H.; Bammens, B.; Verbeke, K.; Vanrenterghem, Y.; Evenepoel, P. p-cresyl sulfate and indoxyl sulfate in hemodialysis patients. Clin. J. Am. Soc. Nephrol. 2009, 4, 1932-1938. [CrossRef] [PubMed]

62. Hirata, K.; Ikeda, T.; Watanabe, H.; Maruyama, T.; Tanaka, M.; Chuang, V.T.G.; Uchida, Y.; Sakurama, K.; Nishi, K.; Yamasaki, K.; et al. The binding of aripiprazole to plasma proteins in chronic renal failure patients. Toxins 2021, 13, 811. [CrossRef] [PubMed]

63. André, C.; Choukroun, G.; Bennis, Y.; Kamel, S.; Lemaire-Hurtel, A.S.; Masmoudi, K.; Bodeau, S.; Liabeuf, S. Potential interactions between uraemic toxins and drugs: An application in kidney transplant recipients treated with calcineurin inhibitors. Nephrol. Dial. Transplant. 2021, 1-9. [CrossRef] [PubMed]

64. Meyer, T.W. Increasing Dialysate Flow and Dialyzer Mass Transfer Area Coefficient to Increase the Clearance of Protein-bound Solutes. J. Am. Soc. Nephrol. 2004, 15, 1927-1935. [CrossRef]

65. Böhringer, F.; Jankowski, V.; Gajjala, P.R.; Zidek, W.; Jankowski, J. Release of uremic retention solutes from protein binding by hypertonic predilution hemodiafiltration. ASAIO J. 2015, 61, 55-60. [CrossRef] [PubMed]

66. Yamamoto, S.; Ito, T.; Sato, M.; Goto, S.; Kazama, J.J.; Gejyo, F.; Narita, I. Adsorption of Protein-Bound Uremic Toxins Using Activated Carbon through Direct Hemoperfusion in vitro. Blood Purif. 2019, 48, 215-222. [CrossRef]

67. Shi, Y.; Tian, H.; Wang, Y.; Shen, Y.; Zhu, Q.; Ding, F. Effect of ionic strength, pH and chemical displacers on the percentage protein binding of protein-bound uremic toxins. Blood Purif. 2019, 47, 351-360. [CrossRef]

68. Tao, X.; Thijssen, S.; Kotanko, P.; Ho, C.H.; Henrie, M.; Stroup, E.; Handelman, G. Improved dialytic removal of protein-bound uraemic toxins with use of albumin binding competitors: An in vitro human whole blood study. Sci. Rep. 2016, 6, 23389. [CrossRef]

69. Madero, M.; Cano, K.B.; Campos, I.; Tao, X.; Maheshwari, V.; Brown, J.; Cornejo, B.; Handelman, G.; Thijssen, S.; Kotanko, P. Removal of protein-bound uremic toxins during hemodialysis using a binding competitor. Clin. J. Am. Soc. Nephrol. 2019, 14, 394-402. [CrossRef]

70. Van Biesen, W.; Eloot, S. Enhanced removal of protein-bound uremic toxins using displacers: Road to success? Clin. J. Am. Soc. Nephrol. 2019, 14, 324-326. [CrossRef] 
71. Shi, Y.; Tian, H.; Wang, Y.; Shen, Y.; Zhu, Q.; Ding, F. Removal of protein-bound uremic toxins by liposome-supported peritoneal dialysis. Perit. Dial. Int. 2019, 39, 509-518. [CrossRef] [PubMed]

72. Shen, Y.; Shen, Y.; Bi, X.; Li, J.; Chen, Y.; Zhu, Q.; Wang, Y.; Ding, F. Linoleic acid-modified liposomes for the removal of protein-bound toxins: An in vitro study. Int. J. Artif. Organs 2021, 44, 393-403. [CrossRef] [PubMed]

73. Ahn, S.Y.; Eraly, S.A.; Tsigelny, I.; Nigam, S.K. Interaction of organic cations with organic anion transporters. J. Biol. Chem. 2009, 284, 31422-31430. [CrossRef]

74. Liu, H.C.; Goldenberg, A.; Chen, Y.; Lun, C.; Wu, W.; Bush, K.T.; Balac, N.; Rodriguez, P.; Abagyan, R.; Nigam, S.K. Molecular Properties of Drugs Interacting with SLC22 Transporters OAT1, OAT3, OCT1, and OCT2: A Machine-Learning Approach. J. Pharmacol. Exp. Ther. 2016, 359, 215-229. [CrossRef]

75. Nigam, A.K.; Ojha, A.A.; Li, J.G.; Shi, D.; Bhatnagar, V.; Nigam, K.B.; Abagyan, R.; Nigam, S.K. Molecular Properties of Drugs Handled by Kidney OATs and Liver OATPs Revealed by Chemoinformatics and Machine Learning: Implications for Kidney and Liver Disease. Pharmaceutics 2021, 13, 1720. [CrossRef] [PubMed]

76. Lowenstein, J.; Nigam, S.K. Uremic Toxins in Organ Crosstalk. Front. Med. 2021, 8, 592602. [CrossRef]

77. Bleasby, K.; Castle, J.C.; Roberts, C.J.; Cheng, C.; Bailey, W.J.; Sina, J.F.; Kulkarni, A.V.; Hafey, M.J.; Evers, R.; Johnson, J.M.; et al. Expression profiles of 50 xenobiotic transporter genes in humans and pre-clinical species: A resource for investigations into drug disposition. Xenobiotica 2006, 36, 963-988. [CrossRef]

78. Nigam, S.K.; Bush, K.T.; Martovetsky, G.; Ahn, S.-Y.; Liu, H.C.; Richard, E.; Bhatnagar, V.; Wu, W. The Organic Anion Transporter (OAT) Family: A Systems Biology Perspective. Physiol. Rev. 2015, 95, 83-123. [CrossRef]

79. Roth, M.; Obaidat, A.; Hagenbuch, B. OATPs, OATs and OCTs: The organic anion and cation transporters of the SLCO and SLC22A gene superfamilies. Br. J. Pharmacol. 2012, 165, 1260-1287. [CrossRef]

80. Breljak, D.; Ljubojević, M.; Hagos, Y.; Micek, V.; Balen Eror, D.; Vrhovac Madunić, I.; Brzica, H.; Karaica, D.; Radovic, N.; Kraus, O.; et al. Distribution of the organic anion transporters NaDC3 and OAT1-3 along the human nephron. Am. J. Physiol. Ren. Physiol. 2016, 311, F227-F238. [CrossRef]

81. Bush, K.T.; Singh, P.; Nigam, S.K. Gut-derived uremic toxin handling in vivo requires OAT-mediated tubular secretion in chronic kidney disease. JCI Insight 2020, 5, e133817. [CrossRef] [PubMed]

82. Motohashi, H.; Nakao, Y.; Masuda, S.; Katsura, T.; Kamba, T.; Ogawa, O.; Inui, K.-I. Precise Comparison of Protein Localization Among OCT, OAT, and MATE in Human Kidney. J. Pharmacol. Sci. 2013, 102, 3302-3308. [CrossRef] [PubMed]

83. Torres, A.M.; Mac Laughlin, M.; Muller, A.; Brandoni, A.; Anzai, N.; Endou, H. Altered renal elimination of organic anions in rats with chronic renal failure. Biochim. Biophys. Acta 2005, 1740, 29-37. [CrossRef]

84. Naud, J.; Roger, M.; Leblond, F.A.; Pichette, V. Effects of Chronic Renal Failure on Kidney Drug Transporters and Cytochrome P450 in Rats. Drug Metab. Dispos. 2011, 39, 1363-1369. [CrossRef] [PubMed]

85. Ji, L.; Masuda, S.; Saito, H.; Inui, K.-I. Down-regulation of rat organic cation transporter rOCT2 by $5 / 6$ nephrectomy. Kidney Int 2002, 62, 514-524. [CrossRef]

86. Deguchi, T.; Takemoto, M.; Uehara, N.; Lindup, W.E.; Suenaga, A.; Otagiri, M. Renal clearance of endogenous hippurate correlates with expression levels of renal organic anion transporters in uremic rats. J. Pharmacol. Exp. Ther. 2005, 314, 932-938. [CrossRef]

87. Enomoto, A.; Takeda, M.; Tojo, A.; Sekine, T.; Cha, S.H.; Khamdang, S.; Takayama, F.; Aoyama, I.; Nakamura, S.; Endou, H.; et al Role of Organic Anion Transporters in the Tubular Transport of Indoxyl Sulfate and the Induction of its Nephrotoxicity. J. Am. Soc. Nephrol. 2002, 13, 1711-1720. [CrossRef]

88. Wikoff, W.R.; Nagle, M.A.; Kouznetsova, V.L.; Tsigelny, I.F.; Nigam, S.K. Untargeted Metabolomics Identifies Enterobiome Metabolites and Putative Uremic Toxins as Substrates of Organic Anion Transporter 1 (Oat1). J. Proteome Res. 2011, 10, $2842-2851$. [CrossRef]

89. Wu, W.; Bush, K.T.; Nigam, S.K. Key Role for the Organic Anion Transporters, OAT1 and OAT3, in the in vivo Handling of Uremic Toxins and Solutes. Sci. Rep. 2017, 7, 4939. [CrossRef]

90. Nigam, S.K. The SLC22 Transporter Family: A Paradigm for the Impact of Drug Transporters on Metabolic Pathways, Signaling, and Disease. Annu. Rev. Pharmacol. Toxicol. 2018, 58, 663-687. [CrossRef]

91. Nagle, M.A.; Truong, D.M.; Dnyanmote, A.V.; Ahn, S.-Y.; Eraly, S.A.; Wu, W.; Nigam, S.K. Analysis of Three-dimensional Systems for Developing and Mature Kidneys Clarifies the Role of OAT1 and OAT3 in Antiviral Handling. J. Biol. Chem. 2011, 286, $243-251$. [CrossRef] [PubMed]

92. Deguchi, T.; Kouno, Y.; Terasaki, T.; Takadate, A.; Otagiri, M. Differential Contributions of rOat1 (Slc22a6) and rOat3 (Slc22a8) to the in Vivo Renal Uptake of Uremic Toxins in Rats. Pharm. Res. 2005, 22, 619-627. [CrossRef]

93. Miyamoto, Y.; Watanabe, H.; Noguchi, T.; Kotani, S.; Nakajima, M.; Kadowaki, D.; Otagiri, M.; Maruyama, T. Organic anion transporters play an important role in the uptake of p-cresyl sulfate, a uremic toxin, in the kidney. Nephrol. Dial. Transplant. 2011, 26, 2498-2502. [CrossRef] [PubMed]

94. Deguchi, T.; Ohtsuki, S.; Otagiri, M.; Takanaga, H.; Asaba, H.; Mori, S.; Terasaki, T. Major role of organic anion transporter 3 in the transport of indoxyl sulfate in the kidney. Kidney Int. 2002, 61, 1760-1768. [CrossRef] [PubMed]

95. Maeda, K.; Tian, Y.; Fujita, T.; Ikeda, Y.; Kumagai, Y.; Kondo, T.; Tanabe, K.; Nakayama, H.; Horita, S.; Kusuhara, H.; et al. Inhibitory effects of p-aminohippurate and probenecid on the renal clearance of adefovir and benzylpenicillin as probe drugs for organic anion transporter (OAT) 1 and OAT3 in humans. Eur. J. Pharm. Sci. 2014, 59, 94-103. [CrossRef] 
96. Zou, L.; Matsson, P.; Stecula, A.; Ngo, H.X.; Zur, A.A.; Giacomini, K.M. Drug Metabolites Potently Inhibit Renal Organic Anion Transporters, OAT1 and OAT3. J. Pharm. Sci. 2021, 110, 347-353. [CrossRef] [PubMed]

97. Taniguchi, T.; Omura, K.; Motoki, K.; Sakai, M.; Chikamatsu, N.; Ashizawa, N.; Takada, T.; Iwanaga, T. Hypouricemic agents reduce indoxyl sulfate excretion by inhibiting the renal transporters OAT1/3 and ABCG2. Sci. Rep. 2021, 11, 7232. [CrossRef] [PubMed]

98. Iwaki, M.; Shimada, H.; Irino, Y.; Take, M.; Egashira, S. Inhibition of methotrexate uptake via organic anion transporters OAT1 and OAT3 by glucuronides of nonsteroidal anti-inflammatory drugs. Biol. Pharm. Bull. 2017, 40, 926-931. [CrossRef]

99. Hotchkiss, A.G.; Gao, T.; Khan, U.; Berrigan, L.; Li, M.; Ingraham, L.; Pelis, R.M. Organic Anion Transporter 1 Is Inhibited by Multiple Mechanisms and Shows a Transport Mode Independent of Exchange. Drug Metab. Dispos. 2015, 43, 1847-1854. [CrossRef] [PubMed]

100. Watanabe, H.; Sakaguchi, Y.; Sugimoto, R.; Kaneko, K.; Iwata, H.; Kotani, S.; Nakajima, M.; Ishima, Y.; Otagiri, M.; Maruyama, T. Human organic anion transporters function as a high-capacity transporter for p-cresyl sulfate, a uremic toxin. Clin. Exp. Nephrol. 2013, 18, 814-820. [CrossRef]

101. Favretto, G.; Souza, L.M.; Gregório, P.C.; Cunha, R.S.; Maciel, R.A.P.; Sassaki, G.L.; Toledo, M.G.; Pecoits-Filho, R.; Souza, W.M.; Stinghen, A.E.M. Role of Organic Anion Transporters in the Uptake of Protein-Bound Uremic Toxins by Human Endothelial Cells and Monocyte Chemoattractant Protein-1 Expression. J. Vasc. Res. 2017, 54, 170-179. [CrossRef] [PubMed]

102. Watanabe, H.; Miyamoto, Y.; Enoki, Y.; Ishima, Y.; Kadowaki, D.; Kotani, S.; Nakajima, M.; Tanaka, M.; Matsushita, K.; Mori, Y.; et al. p-Cresyl sulfate, a uremic toxin, causes vascular endothelial and smooth muscle cell damages by inducing oxidative stress. Pharmacol. Res. Perspect. 2015, 3, e00092. [CrossRef] [PubMed]

103. Ito, S.; Osaka, M.; Higuchi, Y.; Nishijima, F.; Ishii, H.; Yoshida, M. Indoxyl sulfate induces leukocyte-endothelial interactions through up-regulation of E-selectin. J. Biol. Chem. 2010, 285, 38869-38875. [CrossRef] [PubMed]

104. Kim, Y.-H.; Kwak, K.-A.; Gil, H.-W.; Song, H.-Y.; Hong, S.-Y. Indoxyl sulfate promotes apoptosis in cultured osteoblast cells. BMC Pharmacol. Toxicol. 2013, 14, 60. [CrossRef] [PubMed]

105. Mozar, A.; Louvet, L.; Godin, C.; Mentaverri, R.; Brazier, M.; Kamel, S.; Massy, Z.A. Indoxyl sulphate inhibits osteoclast differentiation and function. Nephrol. Dial. Transplant. 2012, 27, 2176-2181. [CrossRef]

106. Enoki, Y.; Watanabe, H.; Arake, R.; Sugimoto, R.; Imafuku, T.; Tominaga, Y.; Ishima, Y.; Kotani, S.; Nakajima, M.; Tanaka, M.; et al. Indoxyl sulfate potentiates skeletal muscle atrophy by inducing the oxidative stress-mediated expression of myostatin and atrogin-1. Sci. Rep. 2016, 6, 32084. [CrossRef]

107. Luo, S.-S.; Yu, C.-P.; Hsieh, Y.-W.; Chao, P.-D.L.; Sweet, D.H.; Hou, Y.-C.; Lin, S.-P. Effects of antibiotics on the pharmacokinetics of indoxyl sulfate, a nephro-cardiovascular toxin. Xenobiotica 2020, 50, 588-592. [CrossRef]

108. VanWert, A.L.; Srimaroeng, C.; Sweet, D.H. Organic Anion Transporter 3 (Oat3/Slc22a8 ) Interacts with Carboxyfluoroquinolones, and Deletion Increases Systemic Exposure to Ciprofloxacin. Mol. Pharmacol. 2008, 74, 122-131. [CrossRef]

109. Li, D.Y.; Wang, Z.; Jia, X.; Yan, D.; Shih, D.M.; Hazen, S.L.; Lusis, A.J.; Tang, W.H.W. Loop Diuretics Inhibit Renal Excretion of Trimethylamine N-Oxide. JACC Basic Transl. Sci. 2021, 6, 103-115. [CrossRef]

110. Teft, W.A.; Morse, B.L.; Leake, B.F.; Wilson, A.; Mansell, S.E.; Hegele, R.A.; Ho, R.H.; Kim, R.B. Identification and Characterization of Trimethylamine-N-oxide Uptake and Efflux Transporters. Mol. Pharm. 2017, 14, 310-318. [CrossRef]

111. Granados, J.C.; Richelle, A.; Gutierrez, J.M.; Zhang, P.; Zhang, X.; Bhatnagar, V.; Lewis, N.E.; Nigam, S.K. Coordinate regulation of systemic and kidney tryptophan metabolism by the drug transporters OAT1 and OAT3. J. Biol. Chem. 2021, $296,100575$. [CrossRef] [PubMed]

112. André, C.; Mernissi, T.; Choukroun, G.; Bennis, Y.; Kamel, S.; Liabeuf, S.; Bodeau, S. The Prescription of Drugs That Inhibit Organic Anion Transporters 1 or 3 Is Associated with the Plasma Accumulation of Uremic Toxins in Kidney Transplant Recipients. Toxins 2021, 14, 15. [CrossRef] [PubMed]

113. Lepist, E.-I.; Zhang, X.; Hao, J.; Huang, J.; Kosaka, A.; Birkus, G.; Murray, B.P.; Bannister, R.; Cihlar, T.; Huang, Y.; et al Contribution of the organic anion transporter OAT2 to the renal active tubular secretion of creatinine and mechanism for serum creatinine elevations caused by cobicistat. Kidney Int. 2014, 86, 350-357. [CrossRef]

114. Shen, H.; Liu, T.; Morse, B.L.; Zhao, Y.; Zhang, Y.; Qiu, X.; Chen, C.; Lewin, A.C.; Wang, X.T.; Liu, G.; et al. Characterization of Organic Anion Transporter 2 (SLC22A7): A Highly Efficient Transporter for Creatinine and Species-Dependent Renal Tubular Expression. Drug Metab. Dispos. 2015, 43, 984-993. [CrossRef] [PubMed]

115. Koepsell, H. Substrate recognition and translocation by polyspecific organic cation transporters. Biol. Chem. 2011, 392, 95-101. [CrossRef]

116. Schophuizen, C.M.S.; Wilmer, M.J.; Jansen, J.; Gustavsson, L.; Hilgendorf, C.; Hoenderop, J.G.J.; Van Den Heuvel, L.P.; Masereeuw, R. Cationic uremic toxins affect human renal proximal tubule cell functioning through interaction with the organic cation transporter. Pflug. Arch. Eur. J. Physiol. 2013, 465, 1701-1714. [CrossRef]

117. Scotcher, D.; Arya, V.; Yang, X.; Zhao, P.; Zhang, L.; Huang, S.M.; Rostami-Hodjegan, A.; Galetin, A. Mechanistic Models as Framework for Understanding Biomarker Disposition: Prediction of Creatinine-Drug Interactions. CPT Pharmacomet. Syst. Pharmacol. 2020, 9, 282-293. [CrossRef]

118. Kimura, N.; Masuda, S.; Katsura, T.; Inui, K. ichi Transport of guanidine compounds by human organic cation transporters, hOCT1 and hOCT2. Biochem. Pharmacol. 2009, 77, 1429-1436. [CrossRef] 
119. Reznichenko, A.; Sinkeler, S.J.; Snieder, H.; van den Born, J.; de Borst, M.H.; Damman, J.; van Dijk, M.C.R.F.; van Goor, H.; Hepkema, B.G.; Hillebrands, J.L.; et al. SLC22A2 is associated with tubular creatinine secretion and bias of estimated GFR in renal transplantation. Physiol. Genom. 2013, 45, 201-209. [CrossRef]

120. Urakami, Y.; Kimura, N.; Okuda, M.; Inui, K. Creatinine Transport by Basolateral Organic Cation Transporter hOCT2 in the Human Kidney. Pharm. Res. 2004, 21, 976-981. [CrossRef]

121. Motohashi, H.; Sakurai, Y.; Saito, H.; Masuda, S.; Urakami, Y.; Goto, M.; Fukatsu, A.; Ogawa, O.; Inui, K. Gene expression levels and immunolocalization of organic ion transporters in the human kidney. J. Am. Soc. Nephrol. 2002, 13, 866-874. [CrossRef] [PubMed]

122. Hacker, K.; Maas, R.; Kornhuber, J.; Fromm, M.F.; Zolk, O. Substrate-dependent inhibition of the human organic cation transporter OCT2: A comparison of metformin with experimental substrates. PLoS ONE 2015, 10, e0136451. [CrossRef] [PubMed]

123. Cheung, K.W.K.; Hsueh, C.-H.; Zhao, P.; Meyer, T.W.; Zhang, L.; Huang, S.-M.; Giacomini, K.M. The Effect of Uremic Solutes on the Organic Cation Transporter 2. J. Pharm. Sci. 2017, 106, 2551-2557. [CrossRef] [PubMed]

124. Winter, T.N.; Elmquist, W.F.; Fairbanks, C.A. OCT2 and MATE1 Provide Bidirectional Agmatine Transport. Mol. Pharm. 2011, 8 , 133-142. [CrossRef]

125. Gessner, A.; König, J.; Fromm, M.F. Contribution of multidrug and toxin extrusion protein 1 (MATE1) to renal secretion of trimethylamine-N-oxide (TMAO). Sci. Rep. 2018, 8, 6659. [CrossRef]

126. Miyake, T.; Mizuno, T.; Mochizuki, T.; Kimura, M.; Matsuki, S.; Irie, S.; Ieiri, I.; Maeda, K.; Kusuhara, H. Involvement of Organic Cation Transporters in the Kinetics of Trimethylamine N-oxide. J. Pharm. Sci. 2017, 106, 2542-2550. [CrossRef]

127. Nakada, T.; Kudo, T.; Kume, T.; Kusuhara, H.; Ito, K. Estimation of changes in serum creatinine and creatinine clearance caused by renal transporter inhibition in healthy subjects. Drug Metab. Pharmacokinet. 2019, 34, 233-238. [CrossRef]

128. Ciarimboli, G.; Lancaster, C.S.; Schlatter, E.; Franke, R.M.; Sprowl, J.A.; Pavenstädt, H.; Massmann, V.; Guckel, D.; Mathijssen, R.H.J.; Yang, W.; et al. Proximal tubular secretion of creatinine by organic cation transporter OCT2 in cancer patients. Clin. Cancer Res. 2012, 18, 1101-1108. [CrossRef]

129. Tanihara, Y.; Masuda, S.; Inui, K. ichi Inhibitory effects of vandetanib on creatinine transport via renal organic cation transporter OCT2. Eur. J. Pharm. Sci. 2021, 158, 105666. [CrossRef]

130. Han, C.; Zheng, J.; Wang, F.; Lu, Q.; Chen, Q.; Hu, A.; Visentin, M.; Kullak-Ublick, G.A.; Gai, Z.; Chu, L. The Role of NF-kB in the Downregulation of Organic Cation Transporter 2 Expression and Renal Cation Secretion in Kidney Disease. Front. Med. 2022, 8, 800421. [CrossRef]

131. Wang, Z.J.; Yin, O.Q.P.; Tomlinson, B.; Chow, M.S.S. OCT2 polymorphisms and in-vivo renal functional consequence: Studies with metformin and cimetidine. Pharmacogenet. Genom. 2008, 18, 637-645. [CrossRef] [PubMed]

132. Filipski, K.K.; Mathijssen, R.H.; Mikkelsen, T.S.; Schinkel, A.H.; Sparreboom, A. Contribution of organic cation transporter 2 (OCT2) to cisplatin-induced nephrotoxicity. Clin. Pharmacol. Ther. 2009, 86, 396-402. [CrossRef]

133. Köttgen, A.; Pattaro, C.; Böger, C.A.; Fuchsberger, C.; Olden, M.; Glazer, N.L.; Parsa, A.; Gao, X.; Yang, Q.; Smith, A.V.; et al. New loci associated with kidney function and chronic kidney disease. Nat. Genet. 2010, 42, 376-384. [CrossRef] [PubMed]

134. Tachikawa, M.; Kasai, Y.; Takahashi, M.; Fujinawa, J.; Kitaichi, K.; Terasaki, T.; Hosoya, K.I. The blood-cerebrospinal fluid barrier is a major pathway of cerebral creatinine clearance: Involvement of transporter-mediated process. J. Neurochem. 2008, 107, 432-442. [CrossRef] [PubMed]

135. Wang, P.; Hata, S.; Xiao, Y.; Murray, J.W.; Wolkoff, A.W. Topological assessment of Oatp1a1: A 12-transmembrane domain integral membrane protein with three N-linked carbohydrate chains. Am. J. Physiol. Gastrointest. Liver Physiol. 2008, 294, G1052-G1059. [CrossRef] [PubMed]

136. Hagenbuch, B.; Stieger, B. The SLCO (former SLC21) superfamily of transporters. Mol. Asp. Med. 2013, 34, 396-412. [CrossRef] [PubMed]

137. El-Mesallamy, H.O.; Abdel Hamid, S.G.; Gad, M.Z. Oxidative stress and asymmetric dimethylarginine are associated with cardiovascular complications in hemodialysis patients: Improvements by L-arginine intake. Kidney Blood Press. Res. 2008, 31, 189-195. [CrossRef]

138. Kajimoto, H.; Kai, H.; Aoki, H.; Yasuoka, S.; Anegawa, T.; Aoki, Y.; Ueda, S.; Okuda, S.; Imaizumi, T. Inhibition of eNOS phosphorylation mediates endothelial dysfunction in renal failure: New effect of asymmetric dimethylarginine. Kidney Int. 2012, 81, 762-768. [CrossRef]

139. Shafi, T.; Hostetter, T.H.; Meyer, T.W.; Hwang, S.; Hai, X.; Melamed, M.L.; Banerjee, T.; Coresh, J.; Powe, N.R. Serum Asymmetric and Symmetric Dimethylarginine and Morbidity and Mortality in Hemodialysis Patients. Am. J. Kidney Dis. 2017, 70, 48-58. [CrossRef]

140. Taghikhani, E.; Maas, R.; Fromm, M.F.; König, J. The renal transport protein OATP4C1 mediates uptake of the uremic toxin asymmetric dimethylarginine (ADMA) and efflux of cardioprotective L-homoarginine. PLoS ONE 2019, 14, e0213747. [CrossRef]

141. Taghikhani, E.; Maas, R.; Taudte, R.V.; Gessner, A.; Fromm, M.F.; König, J. Vectorial transport of the arginine derivatives asymmetric dimethylarginine (ADMA) and L-homoarginine by OATP4C1 and P-glycoprotein studied in double-transfected MDCK cells. Amino Acids 2020, 52, 975-985. [CrossRef] [PubMed]

142. Toyohara, T.; Suzuki, T.; Morimoto, R.; Akiyama, Y.; Souma, T.; Shiwaku, H.O.; Takeuchi, Y.; Mishima, E.; Abe, M.; Tanemoto, M.; et al. SLCO4C1 Transporter Eliminates Uremic Toxins and Attenuates Hypertension and Renal Inflammation. J. Am. Soc. Nephrol. 2009, 20, 2546-2555. [CrossRef] [PubMed] 
143. Akiyama, Y.; Kikuchi, K.; Saigusa, D.; Suzuki, T.; Takeuchi, Y.; Mishima, E.; Yamamoto, Y.; Ishida, A.; Sugawara, D.; Jinno, D.; et al. Indoxyl Sulfate Down-Regulates SLCO4C1 Transporter through Up-Regulation of GATA3. PLoS ONE 2013, 8, e66518. [CrossRef]

144. Mikkaichi, T.; Suzuki, T.; Onogawa, T.; Tanemoto, M.; Mizutamari, H.; Okada, M.; Chaki, T.; Masuda, S.; Tokui, T.; Eto, N.; et al. Isolation and characterization of a digoxin transporter and its rat homologue expressed in the kidney. Proc. Natl. Acad. Sci. USA 2004, 101, 3569-3574. [CrossRef] [PubMed]

145. Fujita, K.I.; Sugiura, T.; Okumura, H.; Umeda, S.; Nakamichi, N.; Watanabe, Y.; Suzuki, H.; Sunakawa, Y.; Shimada, K.; Kawara, K.; et al. Direct inhibition and down-regulation by uremic plasma components of hepatic uptake transporter for sn-38, an active metabolite of irinotecan, in humans. Pharm. Res. 2014, 31, 204-215. [CrossRef]

146. Fujita, K.; Masuo, Y.; Okumura, H.; Watanabe, Y.; Suzuki, H.; Sunakawa, Y.; Shimada, K.; Kawara, K.; Akiyama, Y.; Kitamura, M.; et al. Increased Plasma Concentrations of Unbound SN-38, the Active Metabolite of Irinotecan, in Cancer Patients with Severe Renal Failure. Pharm. Res. 2016, 33, 269-282. [CrossRef]

147. Bøttger, P.; Pedersen, L. Mapping of the minimal inorganic phosphate transporting unit of human PiT2 suggests a structure universal to PiT-related proteins from all kingdoms of life. BMC Biochem. 2011, 12, 21. [CrossRef]

148. Forster, I.C.; Hernando, N.; Biber, J.; Murer, H. Phosphate transporters of the SLC20 and SLC34 families. Mol. Asp. Med. 2013, 34, 386-395. [CrossRef]

149. Inden, M.; Iriyama, M.; Zennami, M.; Sekine, S.I.; Hara, A.; Yamada, M.; Hozumi, I. The type III transporters (PiT-1 and PiT-2) are the major sodium-dependent phosphate transporters in the mice and human brains. Brain Res. 2016, 1637, 128-136. [CrossRef]

150. Ravera, S.; Virkki, L.V.; Murer, H.; Forster, I.C. Deciphering PiT transport kinetics and substrate specificity using electrophysiology and flux measurements. Am. J. Physiol. Cell Physiol. 2007, 293, 606-620. [CrossRef]

151. Shanahan, C.M.; Crouthamel, M.H.; Kapustin, A.; Giachelli, C.M. Arterial calcification in chronic kidney disease: Key roles for calcium and phosphate. Circ. Res. 2011, 109, 697-711. [CrossRef] [PubMed]

152. Barreto, F.C.; Barreto, D.V.; Massy, Z.A.; Drüeke, T.B. Strategies for Phosphate Control in Patients With CKD. Kidney Int. Rep. 2019, 4, 1043-1056. [CrossRef] [PubMed]

153. Six, I.; Maizel, J.; Barreto, F.C.; Rangrez, A.Y.; Dupont, S.; Slama, M.; Tribouilloy, C.; Choukroun, G.; Maziere, J.C.; Bode-Boeger, S.; et al. Effects of phosphate on vascular function under normal conditions and influence of the uraemic state. Cardiovasc. Res. 2012, 96, 130-139. [CrossRef] [PubMed]

154. Abbasian, N.; Burton, J.O.; Herbert, K.E.; Tregunna, B.-E.; Brown, J.R.; Ghaderi-Najafabadi, M.; Brunskill, N.J.; Goodall, A.H.; Bevington, A. Hyperphosphatemia, Phosphoprotein Phosphatases, and Microparticle Release in Vascular Endothelial Cells. J. Am. Soc. Nephrol. 2015, 26, 2152-2162. [CrossRef] [PubMed]

155. Chavkin, N.W.; Chia, J.J.; Crouthamel, M.H.; Giachelli, C.M. Phosphate uptake-independent signaling functions of the type III sodium-dependent phosphate transporter, PiT-1, in vascular smooth muscle cells. Exp. Cell Res. 2015, 333, 39-48. [CrossRef]

156. Li, X.; Yang, H.Y.; Giachelli, C.M. Role of the sodium-dependent phosphate cotransporter, Pit-1, in vascular smooth muscle cell calcification. Circ. Res. 2006, 98, 905-912. [CrossRef]

157. Eto, N.; Miyata, Y.; Ohno, H.; Yamashita, T. Nicotinamide prevents the development of hyperphosphataemia by suppressing intestinal sodium-dependent phosphate transporter in rats with adenine-induced renal failure. Nephrol. Dial. Transplant. 2005, 20, 1378-1384. [CrossRef]

158. Nies, A.T.; Damme, K.; Kruck, S.; Schaeffeler, E.; Schwab, M. Structure and function of multidrug and toxin extrusion proteins (MATEs) and their relevance to drug therapy and personalized medicine. Arch. Toxicol. 2016, 90, 1555-1584. [CrossRef]

159. Tanihara, Y.; Masuda, S.; Sato, T.; Katsura, T.; Ogawa, O.; Inui, K.-i. Substrate specificity of MATE1 and MATE2-K, human multidrug and toxin extrusions $/ \mathrm{H}^{+}$-organic cation antiporters. Biochem. Pharmacol. 2007, 74, 359-371. [CrossRef]

160. Masuda, S.; Terada, T.; Yonezawa, A.; Tanihara, Y.; Kishimoto, K.; Katsura, T.; Ogawa, O.; Inui, K.I. Identification and functional characterization of a new human kidney-specific $\mathrm{H}^{+}$/ organic cation antiporter, kidney-specific multidrug and toxin extrusion 2 . $J$. Am. Soc. Nephrol. 2006, 17, 2127-2135. [CrossRef]

161. Omote, S.; Matsuoka, N.; Arakawa, H.; Nakanishi, T.; Tamai, I. Effect of tyrosine kinase inhibitors on renal handling of creatinine by MATE1. Sci. Rep. 2018, 8, 9237. [CrossRef] [PubMed]

162. Deutsch, B.; Neumeister, C.; Schwantes, U.; Fromm, M.F.; König, J. Interplay of the Organic Cation Transporters OCT1 and OCT2 with the Apically Localized Export Protein MATE1 for the Polarized Transport of Trospium. Mol. Pharm. 2019, 16, 510-517. [CrossRef] [PubMed]

163. George, B.; Wen, X.; Jaimes, E.A.; Joy, M.S.; Aleksunes, L.M. In vitro inhibition of renal oct2 and mate1 secretion by antiemetic drugs. Int. J. Mol. Sci. 2021, 22, 6439. [CrossRef]

164. Nishihara, K.; Masuda, S.; Ji, L.; Katsura, T.; Inui, K.I. Pharmacokinetic significance of luminal multidrug and toxin extrusion 1 in chronic renal failure rats. Biochem. Pharmacol. 2007, 73, 1482-1490. [CrossRef]

165. Shigeta, J.; Katayama, K.; Mitsuhashi, J.; Noguchi, K.; Sugimoto, Y. BCRP/ABCG2 confers anticancer drug resistance without covalent dimerization. Cancer Sci. 2010, 101, 1813-1821. [CrossRef] [PubMed]

166. Wang, H.; Lee, E.-W.; Cai, X.; Ni, Z.; Zhou, L.; Mao, Q. Membrane topology of the human breast cancer resistance protein (BCRP/ABCG2) determined by epitope insertion and immunofluorescence. Biochemistry 2008, 47, 13778-13787. [CrossRef]

167. Ferreira, R.J.; Bonito, C.A.; Cordeiro, M.N.D.S.; Ferreira, M.-J.U.; dos Santos, D.J.V.A. Structure-function relationships in ABCG2: Insights from molecular dynamics simulations and molecular docking studies. Sci. Rep. 2017, 7, 15534. [CrossRef] 
168. Wang, L.; Prasad, B.; Salphati, L.; Chu, X.; Gupta, A.; Hop, C.E.C.A.; Evers, R.; Unadkat, J.D. Interspecies Variability in Expression of Hepatobiliary Transporters across Human, Dog, Monkey, and Rat as Determined by Quantitative Proteomics. Drug Metab. Dispos. 2015, 43, 367-374. [CrossRef]

169. Morimoto, K.; Tominaga, Y.; Agatsuma, Y.; Miyamoto, M.; Kashiwagura, S.; Takahashi, A.; Sano, Y.; Yano, K.; Kakinuma, C.; Ogihara, T.; et al. Intestinal secretion of indoxyl sulfate as a possible compensatory excretion pathway in chronic kidney disease. Biopharm. Drug Dispos. 2018, 39, 328-334. [CrossRef]

170. Maliepaard, M.; Scheffer, G.L.; Faneyte, I.F.; Van Gastelen, M.A.; Pijnenborg, A.C.L.M.; Schinkel, A.H.; Van de Vijver, M.J.; Scheper, R.J.; Schellens, J.H.M. Subcellular localization and distribution of the Breast Resistance Protein Transporter in normal human tissues. Cancer Res. 2001, 61, 3458-3464.

171. Cooray, H.C.; Blackmore, C.G.; Maskell, L.; Barrand, M.A. Localisation of breast cancer resistance protein in microvessel endothelium of human brain. Neuroreport 2002, 13, 2059-2063. [CrossRef]

172. Lu, H.; Klaassen, C. Gender Differences in mRNA Expression of ATP-Binding Cassette Efflux and Bile Acid Transporters in Kidney, Liver, and Intestine of 5/6 Nephrectomized Rats. Drug Metab. Dispos. 2008, 36, 16-23. [CrossRef]

173. Nagura, M.; Tamura, Y.; Kumagai, T.; Hosoyamada, M.; Uchida, S. Uric acid metabolism of kidney and intestine in a rat model of chronic kidney disease. Nucleosides Nucleotides Nucleic Acids 2016, 35, 550-558. [CrossRef]

174. Mutsaers, H.A.M.; Caetano-Pinto, P.; Seegers, A.E.M.; Dankers, A.C.A.; van den Broek, P.H.H.; Wetzels, J.F.M.; van den Brand, J.A.J.G.; van den Heuvel, L.P.; Hoenderop, J.G.; Wilmer, M.J.G.; et al. Proximal tubular efflux transporters involved in renal excretion of p-cresyl sulfate and p-cresyl glucuronide: Implications for chronic kidney disease pathophysiology. Toxicol. In Vitro 2015, 29, 1868-1877. [CrossRef]

175. Takada, T.; Yamamoto, T.; Matsuo, H.; Tan, J.K.; Ooyama, K.; Sakiyama, M.; Miyata, H.; Yamanashi, Y.; Toyoda, Y.; Higashino, T.; et al. Identification of ABCG2 as an Exporter of Uremic Toxin Indoxyl Sulfate in Mice and as a Crucial Factor Influencing CKD Progression. Sci. Rep. 2018, 8, 11147. [CrossRef]

176. Jansen, J.; Fedecostante, M.; Wilmer, M.J.; Peters, J.G.; Kreuser, U.M.; van den Broek, P.H.; Mensink, R.A.; Boltje, T.J.; Stamatialis, D.; Wetzels, J.F.; et al. Bioengineered kidney tubules efficiently excrete uremic toxins. Sci. Rep. 2016, 6, 26715. [CrossRef]

177. Dankers, A.C.A.; Mutsaers, H.A.M.; Dijkman, H.B.P.M.; van den Heuvel, L.P.; Hoenderop, J.G.; Sweep, F.C.G.J.; Russel, F.G.M.; Masereeuw, R. Hyperuricemia influences tryptophan metabolism via inhibition of multidrug resistance protein 4 (MRP4) and breast cancer resistance protein (BCRP). Biochim. Biophys. Acta 2013, 1832, 1715-1722. [CrossRef]

178. Mutsaers, H.A.M.; van den Heuvel, L.P.; Ringens, L.H.J.; Dankers, A.C.A.; Russel, F.G.M.; Wetzels, J.F.M.; Hoenderop, J.G.; Masereeuw, R. Uremic toxins inhibit transport by breast cancer resistance protein and multidrug resistance protein 4 at clinically relevant concentrations. PLOS ONE 2011, 6, e18438. [CrossRef]

179. Lu, Y.; Nakanishi, T.; Hosomi, A.; Komori, H.; Tamai, I. In-vitro evidence of enhanced breast cancer resistance protein-mediated intestinal urate secretion by uremic toxins in Caco-2 cells. J. Pharm. Pharmacol. 2015, 67, 170-177. [CrossRef]

180. Nakayama, A.; Matsuo, H.; Takada, T.; Ichida, K.; Nakamura, T.; Ikebuchi, Y.; Ito, K.; Hosoya, T.; Kanai, Y.; Suzuki, H.; et al. ABCG2 is a High-Capacity Urate Transporter and its Genetic Impairment Increases Serum Uric Acid Levels in Humans. Nucleosides Nucleotides Nucleic Acids 2011, 30, 1091-1097. [CrossRef]

181. Nakayama, A.; Matsuo, H.; Nakaoka, H.; Nakamura, T.; Nakashima, H.; Takada, Y.; Oikawa, Y.; Takada, T.; Sakiyama, M.; Shimizu, S.; et al. Common dysfunctional variants of ABCG2 have stronger impact on hyperuricemia progression than typical environmental risk factors. Sci. Rep. 2014, 4, 5227. [CrossRef]

182. Chen, C.-J.; Tseng, C.-C.; Yen, J.-H.; Chang, J.-G.; Chou, W.-C.; Chu, H.-W.; Chang, S.-J.; Liao, W.-T. ABCG2 contributes to the development of gout and hyperuricemia in a genome-wide association study. Sci. Rep. 2018, 8, 3137. [CrossRef]

183. Komori, H.; Yamada, K.; Tamai, I. Hyperuricemia enhances intracellular urate accumulation via down-regulation of cell-surface BCRP/ABCG2 expression in vascular endothelial cells. Biochim. Biophys. Acta Biomembr. 2018, 1860, 973-980. [CrossRef]

184. Berggren, S.; Gall, C.; Wollnitz, N.; Ekelund, M.; Karlbom, U.; Hoogstraate, J.; Schrenk, D.; Lennernäs, H. Gene and Protein Expression of P-Glycoprotein, MRP1, MRP2, and CYP3A4 in the Small and Large Human Intestine. Mol. Pharm. 2007, 4, $252-257$. [CrossRef]

185. Gradhand, U.; Lang, T.; Schaeffeler, E.; Glaeser, H.; Tegude, H.; Klein, K.; Fritz, P.; Jedlitschky, G.; Kroemer, H.K.; Bachmakov, I.; et al. Variability in human hepatic MRP4 expression: Influence of cholestasis and genotype. Pharm. J. 2008, 8, 42-52. [CrossRef]

186. Zhang, Y.; Han, H.; Elmquist, W.F.; Miller, D.W. Expression of various multidrug resistance-associated protein (MRP) homologues in brain microvessel endothelial cells. Brain Res. 2000, 876, 148-153. [CrossRef]

187. Kubota, H.; Ishihara, H.; Langmann, T.; Schmitz, G.; Stieger, B.; Wieser, H.G.; Yonekawa, Y.; Frei, K. Distribution and functional activity of P-glycoprotein and multidrug resistance-associated proteins in human brain microvascular endothelial cells in hippocampal sclerosis. Epilepsy Res. 2006, 68, 213-228. [CrossRef]

188. Naud, J.; Michaud, J.; Boisvert, C.; Desbiens, K.; Leblond, F.A.; Mitchell, A.; Jones, C.; Bonnardeaux, A.; Pichette, V. DownRegulation of Intestinal Drug Transporters in Chronic Renal Failure in Rats. J. Pharmacol. Exp. Ther. 2007, 320, 978-985. [CrossRef]

189. Gai, Z.; Chu, L.; Hiller, C.; Arsenijevic, D.; Penno, C.A.; Montani, J.-P.; Odermatt, A.; Kullak-Ublick, G.A. Effect of chronic renal failure on the hepatic, intestinal, and renal expression of bile acid transporters. Am. J. Physiol. Physiol. 2014, 306, F130-F137. [CrossRef] 
190. El-Sheikh, A.A.K.; van den Heuvel, J.J.M.W.; Koenderink, J.B.; Russel, F.G.M. Interaction of Nonsteroidal Anti-Inflammatory Drugs with Multidrug Resistance Protein $(\mathrm{MRP})_{2} / \mathrm{ABCC}_{2}-$ and $\mathrm{MRP}_{4} / \mathrm{ABCC}_{4}$-Mediated Methotrexate Transport. J. Pharmacol. Exp. Ther. 2007, 320, 229-235. [CrossRef]

191. Reid, G.; Wielinga, P.; Zelcer, N.; van der Heijden, I.; Kuil, A.; de Haas, M.; Wijnholds, J.; Borst, P. The human multidrug resistance protein MRP4 functions as a prostaglandin efflux transporter and is inhibited by nonsteroidal antiinflammatory drugs. Proc. Natl. Acad. Sci. USA 2003, 100, 9244-9249. [CrossRef] [PubMed]

192. Kawase, A.; Yamamoto, T.; Egashira, S.; Iwaki, M. Stereoselective inhibition of methotrexate excretion by glucuronides of nonsteroidal anti-inflammatory drugs via multidrug resistance proteins 2 and 4. J. Pharmacol. Exp. Ther. 2016, 356, 366-374. [CrossRef] [PubMed] 